\title{
The Chironomidae (Diptera) of the Seychelles
}

\author{
O. A. Sæther \\ Museum of Zoology, University of Bergen, Muséplass 3, N-5007 Bergen, Norway.
}

\begin{abstract}
Tanypus complanatus sp. n., Pseudosmittia remigula sp. n, and Polypedilum (Tripodura) silhoettarium sp. n. are described as male imagines and Clunio gerlachi sp. $\mathrm{n}$. as male and female imago. The male imagines of Larsia pallidissima (Kieffer), Gymnometriocnemus (Gymnometriocnemus) mahensis (Kieffer), Pseudosmittia xanthostola (Kieffer) and Polypedilum (Polypedilum) glabripenne (Kieffer) are described for the first time. The male imagines of Paramerina minima (Kieffer), Smittia megalochirus (Kieffer) n. comb., Smittia mahensis (Kieffer) and Pseudosmittia melanostola (Kieffer); and the female imago of Pseudosmittia xanthostola (Kieffer) are redescribed. A key to the known chironomids of the Seychelles is given. Twenty-eight chironomid species are known from the Seychelles, 23 from the island of Mahé, 12 from Silhouette, 3 from Curieuse, 2 from Anonyme and 1 from each of Fregate, North and the coralline Alphonse. The likely marine intertidal species appears to have their closest relatives in Micronesia and the Pacific, while the freshwater chironomid fauna appear to have more Afrotropical relatives.
\end{abstract}

Keywords : chironomids, Seychelles, key, new species, redescriptions.

\section{Introduction}

In 1905 the Percy Sladen Trust Expedition visited the islands of the western Indian Ocean, followed by a second expedition in 1908-9 concentrating on the Seychelles islands. These expeditions were organised and led by Prof. John Stanley Gardiner to complete the earlier work of the 'Challenger' expeditions. Gardiner's intentions were to investigate the biological relationships between the islands of the Seychelles, Mascarenes and Chagos groups and attempt to find evidence for former land connections between the islands. The results of the expedition still form the basis of all discussion of the region's biogeography. Gardiner and the entomologist of the expedition, H. Scott, demonstrated that the granitic Seychelles islands formed a distinct faunal unit, with close associations with Madagascar and India 65 million years ago. The coralline Sey-

\footnotetext{
* Corresponding author :

E-mail: ole.sather@zmb.uib.no
}

chelles islands and the Mascarenes also shared links with the granitic Seychelles, probably resulting from dispersal across the sunken banks at times of lower sea levels 15,000 years ago. In contrast the Chagos and Cargados show typically low-diversity mid-oceanic Indo-Pacific assemblages (Gerlach 2003). The Percy Sladen Trust Expedition remains the most extensive study of the Seychelles islands. The chironomid material from the expedition was described by Kieffer (1911b) and was deposited at The Natural Science Museum (British Museum), in London. There have been several expeditions since the Percy Sladen Trust Expedition but except for a few specimens collected by $\mathrm{H}$. Malicky, Lunz am See, Austria, no chironomids have been identified or described. Recently The Indian Ocean Expedition 2000-2005 «Biodiversity assessment celebrating the centenary of the Percy Sladen Trust Expedition to the Indian Ocean» was initiated with Dr. Justin Gerlach of The Nature Protection Trust of Seychelles, Cambridge, as scientific co-ordinator. Dr. Gerlach asked me to identify and describe the material collected. 


\section{Material}

All previously known species from the Seychelles were originally described by Kieffer (1911b), redescribed by Freeman $(1955$ c, 1956, 1957, 1958) and listed or assigned to present genera by Freeman \& Cranston (1980). The material described by Kieffer as well as the present material is deficient with most of the specimens lacking antennae and tarsi.

\section{Methods and terminology}

The general terminology follows Sæther (1980). All the Pseudosmittia Goetghebuer described here have a forked postcubitus. The ratio $\mathrm{VR}_{2}$ gives the distance from the arculus to the postcubital fork divided by the length of $\mathrm{M}$ from the arculus to $\mathrm{RM}$, corresponding to the venarum ratio, VR (or $\mathrm{VR}_{1}$ ) which gives the distance to the cubital fork divided by the length of $\mathrm{M}$. All material is on microscope slides prepared in Canada balsam. Measurements are given as ranges followed by a mean when 4 or more measurements are given, followed by the number measured (n) in parenthesis. The holotypes of the new species are deposited at the Museum of Zoology, Department of Zoology, University of Bergen, Norway (ZMBN). Paratypes are in The Natural History Museum, London (BMNH), and at University Museum of Zoology, Cambridge (UMZC).

Key to Chironomidae from the Seychelles

1. Wing with crossvein $\mathrm{MCu}$ present. Tanypodinae 2

- Wing lacking crossvein $\mathrm{MCu}$ or brachypterous .

2. Crossvein $\mathrm{MCu}$ before $\mathrm{FCu}$, distance between $\mathrm{FCu}$ and $\mathrm{MCu} 1 / 3$ as long as $\mathrm{Cu}_{1}$; (Figs.1-3) ..... Tanypus complanatus $\mathrm{sp} . \mathrm{n}$.

- Crossvein $\mathrm{MCu}$ beyond $\mathrm{FCu}$

3. Scutal tubercle well developed, all tibial spurs lyrate, costal extension twice as long as $\mathrm{MCu}$ (Figs.4-6) ..............Larsia pallidissima (Kieffer)

- No scutal tubercle, tibial spurs semilyrate, costa not extended; (Figs. 7-8).....Paramerina minima (Kieffer)

4. Hind tibial comb consisting of fused spines, gonostylus rigidly fused to gonocoxite, fore tarsomere 1 longer than fore tibia...Chironominae 15

- Hind tibial comb consisting of free spiniform setae, gonostylus movable, fore tarsomere 1 shorter than fore tibia ..Orthocladiinae 5

5. Wing membrane with setae ; (Figs. 9-11) ....Gymnometriocnemus (G.) mahensis (Kieffer)
- Wing membrane bare .6

6. Eyes hairy, male anal point absent ...................7

Eyes bare, anal point absent or present............ 9

7. Wing broad, about half as wide as long, and rounded in male, absent in female ; 9 flagellomeres in male, 4 in female ; palp 2-segmented; (Figs. 19-26). Clunio gerlachi $\mathrm{sp} . \mathrm{n}$.

- Wing more narrow, at most $1 / 3$ as wide as long; 13 flagellomeres in male; palp 5-segmented ....8

8. Dorsocentrals decumbent, squama fringed..... .Cricotopus quadrifasciatus (Kieffer)

- Dorsocentrals erect, squama bare ..Smittia brevicornis Tokunaga

9. Veins $\mathrm{R}_{1}$ and $\mathrm{R}_{4+5}$ short, tick, fused with costa into clavus, ending before mid-point of wing..... .Corynoneura seychellensis Kieffer

- Veins $\mathrm{R}_{1}$ and $\mathrm{R}_{4+5}$ narrow, elongate, separated from costa until apex beyond mid-point of wing .10

10. About 12-17 weak acrostichals, starting in front ; postcubitus not forked; costal extension more than $110 \mu \mathrm{m}$ long; male anal point long, parallelsided, bare, placed posteriorly on tergite IX....... Smittia Holmgren 11

- Two short, but distinct median acrostichals ; postcubitus forked; costal extension absent or less than $110 \mu \mathrm{m}$ long; male anal point when present placed anteriorly on tergite IX Pseudosmittia Goetghebuer 12

11. Squama with 2 setae ; $R$ with $7-11$ setae, $R_{1}$ with 4-6, $R_{4+5}$ with 7-10 setae; (Figs. 12-14)... Smittia megalochirus (Kieffer)

- Squama bare ; R with 1 seta, other veins bare.... ..Smittia mahensis (Kieffer)

12. Anal point triangular. .13

- Anal point absent or long, bare and parallel-sided.

13. Inferior volsella posterior on gonocoxite, curved; (Figs. 29, 30)

..Pseudosmittia triangula Tokunaga

- Inferior volsella anterior on gonocoxite, extremely long, digitiform; (Figs. 28, 32-36)....

\section{Pseudosmittia xanthostola (Kieffer)}

14. Anal point absent, gonostylus paddle-oar-shaped ; (Fig. 37) ......Pseudosmittia remigula sp. n.

- Anal point long and parallel-sided, gonostylus normal ; (Figs. 27, 31) .

.Pseudosmittia melanostola (Kieffer)

15. Wing membrane with microtrichiae, squama ba- 
re, $\mathrm{RM}$ parallel to $\mathrm{R}_{4+5}$ and continuous with it ; median volsella present Tanytarsus v. d. Wulp 16

- Wing membrane bare, squama fringed, RM oblique to $\mathrm{R}_{4+5}$; median volsella absent ........20

16. Anal point absent, gonostylus very broad ; Figs 38-41) Tanytarsus esakii Tokunaga

- Anal point present, gonostylus normal ...........17

17. Digitus not extending beyond inner margin of superior volsella ; (Figs. 44-46) Tanytarsus pallidulus Freeman

- Digitus clearly extending beyond inner margin of superior volsella ..18

18. Superior volsella large with projection on lateral margin, digitus broad-based ; inferior volsella reaching to about $1 / 2$ length of gonostylus

Tanytarsus atomarius Kieffer

- Superior volsella medium sized, digitus with narrow base; inferior volsella reaching to about $1 / 3$ length of gonostylus

19. Digitus narrow, pointed; wing apparently not cuneiform Tanytarsus pallidissimus Kieffer

- Digitus broad, long, apically rounded; wing cuneiform; (Figs. 42, 43)

Tanytarsus sp. n. near pallidissimus

20. Legs clothed with adpressed scales as well as erect setae, pulvilli absent

Lepidopus nigratipes (Kieffer)

- Legs with setae only, pulvilli present .21

21. Male antenna with 13 flagellomeres; fore tibia with projecting inner scale usually with spur, outer scale absent ; no scutal tubercle; apodeme lobe of female without apical microtrichiae

Polypedilum Kieffer 22

- Male antenna with 11 flagellomeres; fore tibia with inner scale low, rounded, scarcely projecting beyond outer scale ; scutal tubercle present ; apodeme lobe of female with apical microtrichiae

.25

22. Anal point trifid, superior volsella without apical extension; (Fig. 47)

....Polypedilum (Tripodura) silhouettarium sp. n

- Anal point simple, superior volsella with apical extension

23. Superior volsella with apical extension longer than base, wing length about 1.6-1.7 mm .......24

- Superior volsella with apical extension shorter than base or not clearly separable from base, wing length about $0.8 \mathrm{~mm}$; (Fig. 49) Kieffer
24. Gonostylus narrow, nearly parallel-sided ; AR about 0.5 ; (Fig. 48)

........Polypedilum (Polypedilum) melanophilum Kieffer

- Gonostylus narrow, outer margin curved;AR about 1.6.

Kieffer

Polypedilum (Polypedilum) brunneicorne

25. Inferior volsella very broad, superior volsella with inner setae basally and along apical projection; (Figs. 56, 59-61, 62, 65)

Kiefferulus chloronotus (Kieffer)

- Inferior volsella narrow, superior volsella either without setae on apical projection or with apical setae

26. Superior volsella without distinct setaceous base, swollen at apex, with apical setae ; (Figs. 5052) ................Dicrotendipes binotatus (Kieffer)

- Superior volsella with distinct setaceous base ; apical projection tapering, bare .27

27. Superior volsella projection nearly 3 times as long as base, frontal tubercles mostly less than twice as long as wide, wing length more than 2.5 $\mathrm{mm}$; (Figs. 57, 60, 63. 66)

Chironomus seychelleanus Kieffer

- Superior volsella projection about 1.5 times as long as base, frontal tubercles more than 3 times as long as wide, wing length about $2 \mathrm{~mm}$; (Figs. 58, 61, 64, 67)........Chironomus linearis Kieffer

\section{Subfamily Tanypodinae}

\section{Tanypus complanatus sp. $\mathbf{n}$.}

Figures 1-3

Type material : Holotype : $0^{\prime}$, SEYCHELLES : Mahé, Marc aux Cochons, 29 viii 2002, J. Gerlach (ZMBN Type No. 402).

Diagnostic characters : The reduced or absent scutal tubercle combined with the presence of dorsal postnotals and the nearly straight gonostylus separate the species from all other described species of Tanypus Meigen.

Etymology : From the Latin complanatus, flattened, referring to the reduced scutal tubercle.

\section{MALE IMAGO $(n=1)$}

Total length $2.32 \mathrm{~mm}$. Wing length $1.20 \mathrm{~mm}$. Total length/wing length 2.04. Thorax pale with dark vittae, preepisternum and dorsal part of postnotum. Abdomen 
apparently with tergites brown medially, tergites VI and VII fully brown, and tergite VIII, IX and hypopygium whitish. At least hind leg with dark brown femur whitish in apical $1 / 5$, and tibia whitish with apical $1 / 3$ brownish.

Head. Antenna lost. Temporal setae 24, consisting of 14 inner verticals, 7 outer verticals, and 3 postorbitals. Clypeus with 10 setae. Tentorium $146 \mu \mathrm{m}$ long, $30 \mu \mathrm{m}$ wide. Stipes $75 \mu \mathrm{m}$ long. Lengths of three first palpomere (in $\mu \mathrm{m}$ ): 38, 49, 90. Last palpomere lost.

Thorax (Fig. 2). Antepronotum with 4 lateral setae, apparent dorsolateral tubercle small. Scutal tubercle reduced. Dorsocentrals 42, acrostichals 40, prealars 20 , no supraalar seta. Scutellum with 12 uniserial posterior setae, and 24 weaker anterior setae in 2-3 transverse rows. Postnotum with 2 dorsal setae.

Wing (Fig. 1). Apex of wing lost. Membrane brownish, with macrotrichiae on whole wing, with several diffuse spots. $R_{1}$ and $R_{4+5}$ close together and it is not possible to see whether $R_{2+3}$ is present and forked or not. VR 1.25. Anal lobe well developed. Distance between $\mathrm{MCu}$ and $\mathrm{FCu}$ exactly $1 / 3$ length of $\mathrm{Cu}_{1}$. R with 44 setae, $\mathrm{R}_{1}$ with $43, \mathrm{R}_{4+5}$ with more than 36 , subcosta with about $20, \mathrm{RM}$ with $3, \mathrm{M}$ with $8, \mathrm{M}_{1+2}$ with 41 , $\mathrm{M}_{3+4}$ with $10, \mathrm{Cu}$ with $20, \mathrm{Cu}_{1}$ with 6 , postcubitus with 32 , and An with 10 setae. Squama with 12 setae.

Legs. Front and mid legs and hind tarsomeres lost. Spurs of hind tibia $68 \mu \mathrm{m}$ and $34 \mu \mathrm{m}$ long. Width at apex of hind tibia $41 \mu \mathrm{m}$. Comb reduced to 2 setae, $45 \mu \mathrm{m}$ long. Hind femur $588 \mu \mathrm{m}$ long, hind tibia 643 $\mu \mathrm{m}$ long.

Hypopygium (Fig. 3). Tergite IX apparently with only 2 posterior setae. Phallapodeme $79 \mu \mathrm{m}$ long ; sternapodeme triangular, with $15 \mu \mathrm{m}$ long median projection. Gonocoxite $120 \mu \mathrm{m}$ long, gonostylus $105 \mu \mathrm{m}$ long. HR 1.14, HV 2.21.

\section{Remarks}

In many details this damaged specimen does not conform to the generic diagnosis of the genus. However, it conforms even less to the alternative placements such as Djalmabatista Fittkau and Procladius Skuse. Most likely it deserves a separate genus.

\section{Distribution}

The marsh at Marc aux Cochons according to Gerlach (2003) is one of the most important habitats on Mahé supporting a wide variety of aquatic invertebrates including the three tanypodine species known from the Seychelles.

\section{Larsia pallidissima (Kieffer)}

(Figures 4-6)

Isoplastus pallidissimus Kieffer, 1911b: 364.

Pentaneura (Pentaneura) pallidissima (Kieffer); Freeman 1955 c: 30.

Larsia pallidissima (Kieffer) ; Freeman \& Cranston $1980: 179$.

Material examined : SEYCHELLES : Mahé, Marc aux Cochons, 1 o', 29 viii 2002, J. Gerlach (ZMBN).

Diagnostic characters : The extended costa, the small size, and the long phallapodeme distinguish the species from other members of the genus.

\section{MALE IMAGO $(n=1)$}

Total length $2.01 \mathrm{~mm}$. Wing length $1.08 \mathrm{~mm}$. Total length/wing length 1.91. Wing length/length of profemur 2.09. Coloration pale with darker vittae, preepisternum and postnotum, with scutellum slightly less dark. Abdomen pale.

Head. Antenna lost. Temporal setae 16, consisting of 4 inner verticals, 5 outer verticals, and 7 postorbitals. Clypeus with 12 setae. Tentorium $143 \mu \mathrm{m}$ long, $38 \mu \mathrm{m}$ wide. Lengths (in $\mu \mathrm{m}$ ) of three basal palpomeres 30 , 38, 79. Other palpomeres lost.

Thorax (Fig. 5). Antepronotum with 5 lateral setae. Row of 5 tubercles present just posterior to antepronotum. Dorsocentrals 34, acrostichals 25, prealars 18, supraalars 1. Scutal tubercle well developed. Scutellum with 10 uniserial posterior setae, and 12 weaker anterior setae in 1-2 transverse rows. Postnotum without setae.

Wing (Fig. 4). VR 0.86. Costal extension $75 \mu \mathrm{m}$ long, RM $41 \mu \mathrm{m}$ long, MCu $32 \mu \mathrm{m}$ long, distance between $\mathrm{FCu}$ and $\mathrm{MCu} 15 \mu \mathrm{m}$. R with 20 setae ; $\mathrm{R}_{1}$ with 33 ; $\mathrm{R}_{4+5}$ with 48 ; subcosta with about 14 ; $\mathrm{RM}$ with 2 ; $\mathrm{M}$ with 14 ; $\mathrm{Cu}$ with $13 ; \mathrm{M}_{1+2}, \mathrm{M}_{3+4}, \mathrm{Cu} 1$, and postcubitus each with about $40-60$ setae ; An with about 15 setae. Squama with 13 setae.

Legs. Spur of front tibia $45 \mu \mathrm{m}$ long, spurs of middle tibia lost, of hind tibia $30 \mu \mathrm{m}$ and $26 \mu \mathrm{m}$ long. Width at apex of front and middle tibiae each $34 \mu \mathrm{m}$, of hind tibia $41 \mu \mathrm{m}$. Lengths (in $\mu \mathrm{m}$ ) of femora of front to hind leg: 520, 558, 718 ; of front to hind tibiae : 614, 539, 581. Tarsomeres lost.

Hypopygium (Fig. 6). Tergite IX with 9 setae in transverse posterior row. Phallapodeme $75 \mu \mathrm{m}$ long, transverse sternapodeme triangular. Gonocoxite 113 $\mu \mathrm{m}$ long ; gonostylus $79 \mu \mathrm{m}$ long, with $6 \mu \mathrm{m}$ long megaseta. HR 1.43, HV 2.54.

\section{Remarks}

The species does not conform to the generic diagnosis of the genus since the costa is distinctly extended 
and the phallapodeme long. However, in other details it fits the generic diagnosis. Although the single specimen examined is damaged it is described here since the species may deserve a separate genus.

\section{Distribution}

The species previously was known only from the female holotype from Mahé.

\section{Paramerina minima (Kieffer)}

(Figures 7-8)

Isoplastus minimus Kieffer, 1911b: 356.

Pentaneura (Pentaneura) minima (Kieffer) ; Freeman 1955 c: 33.

Paramerina minima (Kieffer) ; Freeman \& Cranston $1980: 179$

Material examined : SEYCHELLES: Mahé, Marc aux Cochons, 1 o', 29 viii 2002; Silhouette 4 o', 6 i 2002; Curieuse, 3 ơ, 20 iii 2003. All J. Gerlach (ZMBN, UMZC).

Diagnostic characters: The species is distinguished by its small size, low antennal ratio, and by having tergite $\mathrm{V}$ and hypopygium pale.

\section{MALE IMAGO}

( $\mathrm{n}=8$ except when otherwise stated)

Total length 2.08-2.42, $2.30 \mathrm{~mm}$. Wing length 1.11$1.25,1.19 \mathrm{~mm}$. Total length/wing length 1.86-2.05, 1.94. Wing length/length of profemur 2.09-2.27, 2.18. Coloration pale with darker vittae and postnotum, and with lower part of preepisternum and scutellum slightly darkened. Tergites I-IV with brown median band; tergite $\mathrm{V}$ pale, but not fully whitish; tergites VI-VIII with broad, brown median band, with tergite VIII nearly fully dark; tergite IX and hypopygium whitish. Legs apparently pale. Wing unmarked.

Head. AR 1.19-1.24 (2). Ultimate antennal segment as in Paramerina anomala Beck \& Beck (Murray \& Fittkau 1989, fig. 5.28A), 23-26 $\mu \mathrm{m}$ (2) long ; penultimate flagellomere141-150 $\mu \mathrm{m}$ (2) long ; apical seta 47 $\mu \mathrm{m}$ (2) long Temporal setae 114-17, 15 ; consisting of 4-6, 5 inner verticals ; 4-6, 5 outer verticals ; and 4-6, 5 postorbitals. Clypeus with $9-13,12$ setae. Tentorium 125-150, $140 \mu \mathrm{m}$ long; 30-36, $31 \mu \mathrm{m}$ wide. Lengths (in $\mu \mathrm{m}$ ) of palpomeres $26-38,32 ; 41-53,48 ; 108-146$, 134 ; 135-163, 150 (5) ; 169-225 (3).

Thorax (Fig.7). Antepronotum with 1-3,2 lateral setae. Row of 4-8, 6 tubercles present just posterior to antepronotum. Dorsocentrals 17-28, 24 ; acrostichals 24-36, 31; prealars 9-11, 10; supraalar 1. Scutellum with 8-10, 10 uniserial posterior setae ; and 12-20, 15 weaker anterior setae in 1-2 transverse rows. Postno- tum without setae.

Wing. Wing venation as in Paramerina cingulata (Walker) (Murray \& Fittkau, 1989 fig. 5.28B). [Chironomus cingulatus Walker, 1856 is a junior primary homonym of $C$. cingulatus Meigen, 1830 . However, the two homonyms have not been placed in the same genus by any author after 1899 and no solution to this homonymy was published prior to 2000 . Under such circumstances, the fourth edition of the nomenclature Code (ICZN, 1999 : Article 23.9.5) now prohibits replacing the junior homonym without applying for an ICZN decision. Consequently, $P$. cingulata (Walker) remains the valid name, its replacement with the junior synonym $P$. pygmaea (van der Wulp, 1874) by Moller Pillot \& Beuk (2002) is invalid. See Spies \& Sæther 2004).] VR 0.84-0.86, 0.88. Costal extension 15-38, $26 \mu \mathrm{m}$ long ; RM 23-30, $26 \mu \mathrm{m}$ long ; MCu 26-32, 28 $\mu \mathrm{m}$ long ; distance between $\mathrm{FCu}$ and $\mathrm{MCu} 0-11,5 \mu \mathrm{m}$. Brachiolum with 2 setae ; $\mathrm{R}$ with $27-38,33$; $\mathrm{R}_{1}$ with 24-48, 35 ; $\mathrm{R}_{4+5}$ with 34-48, 42 ; subcosta with 27-44, 33 ; RM with $0-1,1$; $\mathrm{M}$ with $11-21,15 ; \mathrm{M}_{1+2}$ with 7891,$84 ; \mathrm{M}_{3+4}$ with 27-52, 39 ; $\mathrm{Cu}$ with 12-21, 16; $\mathrm{Cu}_{1}$ with 16-33, 23 ; postcubitus with 39-58, 48 ; An with 20-30, 28 setae. Squama with 10-20, 15 setae.

Legs. Spur of front tibia 30-41, $37 \mu \mathrm{m}$ (7) long ; spurs of middle tibia 49-56, $53 \mu \mathrm{m}$ (7) and 19-26, 24 $\mu \mathrm{m}$ (7) long; of hind tibia 53-64, $57 \mu \mathrm{m}$ and 23-30, 25 $\mu \mathrm{m}$ long. Width at apex of front tibia $24-36,30 \mu \mathrm{m}$; of middle tibia $32-38,34 \mu \mathrm{m}$; of hind tibia $34-39,37 \mu \mathrm{m}$. Lengths (in $\mu \mathrm{m}$ ) of femora of front to hind leg : 520588,$552 ; 614-677,643 ; 520-568,543$; of front to hind tibiae : 572-666, 609; 491-568, 525 ; 609-680, 652. Tarsomeres lost.

Hypopygium (Fig. 8). Tergite IX without posterior setae. Phallapodeme 83-120, $105 \mu \mathrm{m}$ long ; transverse sternapodeme triangular with 19-23, $20 \mu \mathrm{m}$ long anterior projection. Gonocoxite 154-184, $168 \mu \mathrm{m}$ long ; gonostylus 116-131, $123 \mu \mathrm{m}$ long, with $11-15,12 \mu \mathrm{m}$ long megaseta. HR 1.31-1.44, 1.36 ; HV 1.77-1.95, 1.88 .

\section{Remarks}

The species is very similar to other species of the genus. Paramerina vaillanti Fittkau (Fittkau 1962: 335) known from Algeria, the Canary Islands, Jordan, Saudi Arabia, Zimbabwe and South Africa (Cranston \& Judd 1989, Armitage et al. 1995) could conceivably be a junior synonym. However, that species appear to have a much shorter phallapodeme (Fittkau 1962 fig. 269) and a higher antennal ratio.

\section{Distribution}

The species previously was known only from the male holotype from Mahé. 
290

O.A. SÆTHER

(6)
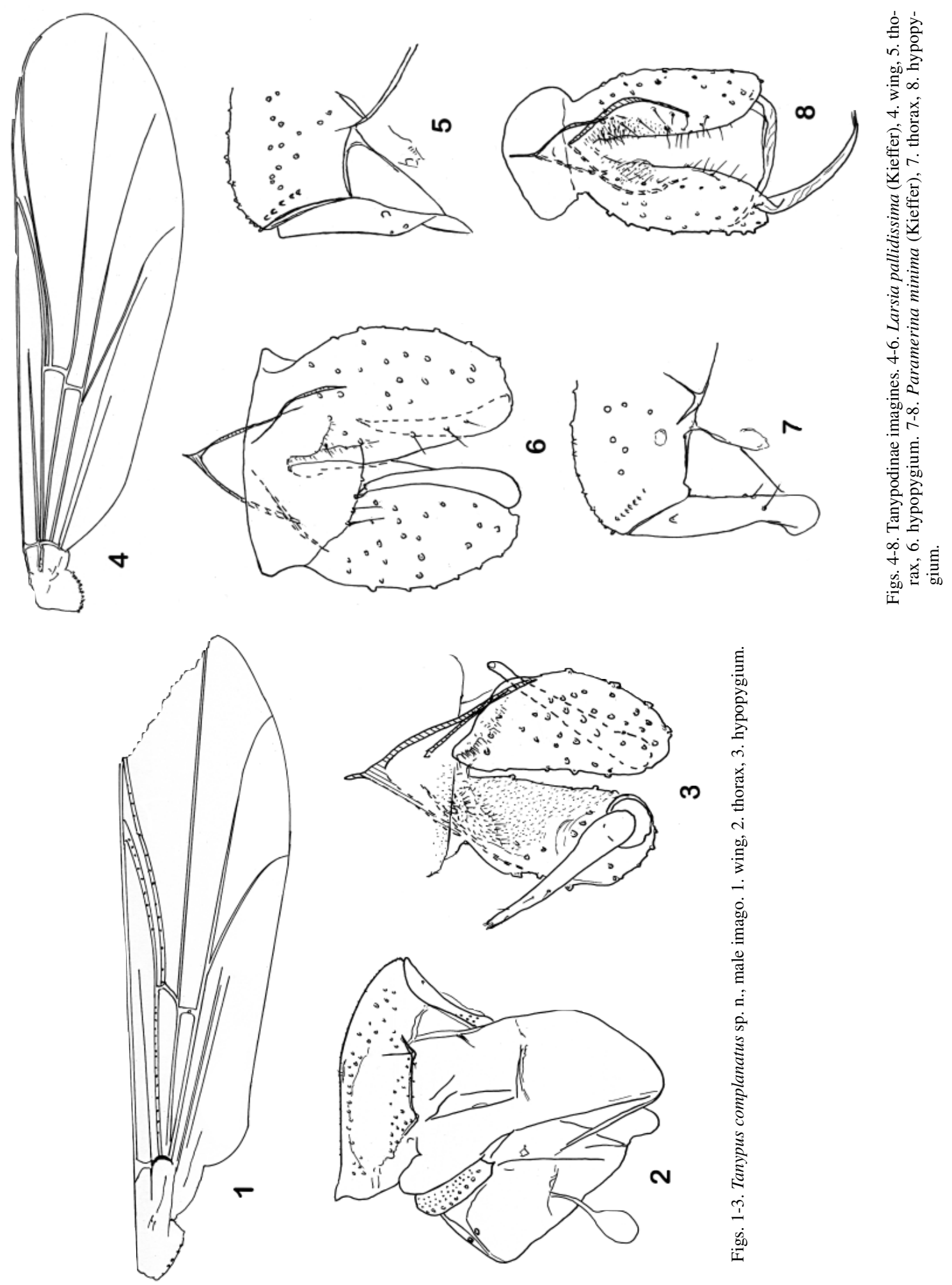


\section{Subfamily Orthocladiinae}

\section{Cricotopus quadrifasciatus (Kieffer)}

Trichocladius quadrifasciatus Kieffer, 1911b: 360.

Cricotopus quadrifasciatus (Kieffer) ; Freeman 1956 : 310, Freeman \& Cranston $1980: 183$.

This species was one of only six previously recorded species not found by The Indian Ocean Expedition. Freeman $(1956: 310)$ redescribed it from the island of Mahé. The species is also known from Mali, Niger and Nigeria.

\section{Gymnometriocnemus (Gymnometriocnemus) ma-} hensis (Kieffer)

(Figures 9-11)

Metriocnemus mahensis Kieffer, 1911b : 360.

Metriocnemus mahensis Kieffer ; Freeman 1956 : 303.

Gymnometriocnemus mahensis (Kieffer) ; Freeman \& Cranston $1980: 183$.

Material examined : SEYCHELLES : Silhouette ; Mon Plaisir, 1 O’, 2 ㅇ, 6 viii 2000, J. Gerlach (ZMBN).

Diagnostic characters : The imagines are characterised by having no eye elongation. The male differs from other members of the genus by having a true anal point and appears to be lacking a virga.

\section{MALE IMAGO $(n=1)$}

Total length $1.90 \mathrm{~mm}$. Wing length $1.00 \mathrm{~mm}$. Total length/wing length 1.90 . Wing length/length of profemur 2.12. Coloration brown.

Head. Antenna lost. Eye without dorsomedian elongation. Temporal setae not measurable. Clypeus with 12 setae. Tentorium $120 \mu \mathrm{m}$ long, $23 \mu \mathrm{m}$ wide. Stipes $101 \mu \mathrm{m}$ long. Palpomeres not measurable.

Thorax. Scutellum with 4 setae. Other details not measurable.

Wing. VR 1.31. Anal lobe reduced, but wing not cuneiform. Costa $150 \mu \mathrm{m}$ long. Brachiolum with 1 seta ; subcosta ; RM and $\mathrm{M}$ bare ; costal extension with 14 non-marginal setae, $\mathrm{R}$ with 20 setae, $\mathrm{R}_{1}$ with $12, \mathrm{R}_{4+5}$ with $23, \mathrm{M}_{1+2}$ with $33, \mathrm{M}_{3+4}$ with $16, \mathrm{Cu}$ with $13, \mathrm{Cu}_{1}$ with 10 , postcubitus with 15 , and An with 9 setae. Squama bare. Cell $\mathrm{m}$ basal of RM with 9 setae, $\mathrm{r}_{4+5}$ with about $55, \mathrm{~m}_{1+2}$ with about $110, \mathrm{~m}_{3+4}$ with 26 , and cells cu and an combined with about 60 setae.

Legs. Spur of front tibia $38 \mu \mathrm{m}$ long, spurs of middle tibia $23 \mu \mathrm{m}$ and $15 \mu \mathrm{m}$ long, of hind tibia $38 \mu \mathrm{m}$ and $17 \mu \mathrm{m}$ long. Width at apex of front tibia $38 \mu \mathrm{m}$, of middle tibia $30 \mu \mathrm{m}$, of hind tibia $36 \mu \mathrm{m}$. Comb of 10 setae, 23-34 $\mu \mathrm{m}$ long. Lengths (in $\mu \mathrm{m}$ ) of front to hind femur as : 473, 473, 510 ; of front to hind tibia ; 501, $468,548$.

Hypopygium (Fig. 9). Anal point $12 \mu \mathrm{m}$ long. Tergite IX apparently with about 22 setae including about 8 on anal point; laterosternite IX apparently with 5 setae. Phallapodeme $79 \mu \mathrm{m}$ long; transverse sternapodeme $49 \mu \mathrm{m}$ long, oral projections well developed. Virga not observed and perhaps absent. Gonocoxite $143 \mu \mathrm{m}$ long. Gonostylus $62 \mu \mathrm{m}$ long, semicircular, with $7 \mu \mathrm{m}$ long megaseta. HR 2.30, HV3.06.

\section{FEMALE IMAGO $(n=1-2)$}

Total length $1.32 \mathrm{~mm}$. Wing length 0.94-1.01 mm. Total length/wing length 1.41. Wing length/length of profemur 2.17-2.25.

Head. Antenna lost. Temporal setae12-14, consisting of 4-5 inner verticals 2-4 outer verticals, and 2-5 postorbitals. Clypeus with 12-14 setae. Tentorium 114$129 \mu \mathrm{m}$ long, 9-11 $\mu \mathrm{m}$ wide. Stipes 98-109 $\mu \mathrm{m}$ long. Palpomere lengths (in $\mu \mathrm{m}$ ): $23,30,45-49,49-51$, and lost.

Thorax. Antepronotum apparently with lateral setae. Dorsocentrals 15, acrostichals 12, prealars 3. Scutellum with 6 setae.

Wing. VR 1.28. Costal extension 143-158 $\mu \mathrm{m}$ long. Brachiolum with 1seta; subcosta, RM and M bare; costal extension with 15-23 non-marginal setae, $\mathrm{R}$ with 11-16 setae, $\mathrm{R}_{1}$ with $10-13, \mathrm{R}_{4+5}$ with $19-20$ setae, $\mathrm{M}_{1+2}$ with $30, \mathrm{M}_{3+4}$ with $19, \mathrm{Cu}$ with $10-11, \mathrm{Cu}_{1}$ with 11 , postcubitus with 16 setae. Squama bare. Cell $\mathrm{m}$ basal of RM with 10 setae, $\mathrm{r}_{4+5}$ with $62, \mathrm{~m}_{1+2}$ with about $120, \mathrm{~m}_{3+4}$ with about 40 , and cells cu and an combined with about 90 setae.

Legs. Spur of front tibia $32 \mu \mathrm{m}$ long, spur of middle tibia $23 \mu \mathrm{m}$ and $15 \mu \mathrm{m}$ long, of hind tibia $38 \mu \mathrm{m}$ and 15-17 $\mu \mathrm{m}$ long. Width at apex of front and middle tibiae each 30-32 $\mu \mathrm{m}$, of hind tibia 34-38 $\mu \mathrm{m}$. Comb of 8-10 setae, $19-23$ to $34 \mu \mathrm{m}$ long. Tarsi lost on all front and middle legs. Lengths (in $\mu \mathrm{m}$ ) of front to hind femora: 416-463, 406-454,435-501; of front to hind tibiae: 435-515, 406-473, 482-558; of hind $\operatorname{ta}_{1}-\mathrm{ta}_{5}$ : 302, 132, 99, 47, 38. $\mathrm{LR}_{3}$ 0.63, $\mathrm{BV}_{3} 3.85, \mathrm{SV}_{3} 3.03$.

Abdomen. T VIII with about 20 setae. Sternite VIII with 22 setae.

Genitalia (Figs 10-11). Gonocoxite apparently 8 setae. Tergite IX divided, apparently with altogether 20 setae. Cercus 64-75 $\mu \mathrm{m}$ long. Seminal capsule 68-71 $\mu \mathrm{m}$ long including $15-17 \mu \mathrm{m}$ long neck, $49 \mu \mathrm{m}$ wide. Notum 58-60 $\mu \mathrm{m}$ long. 

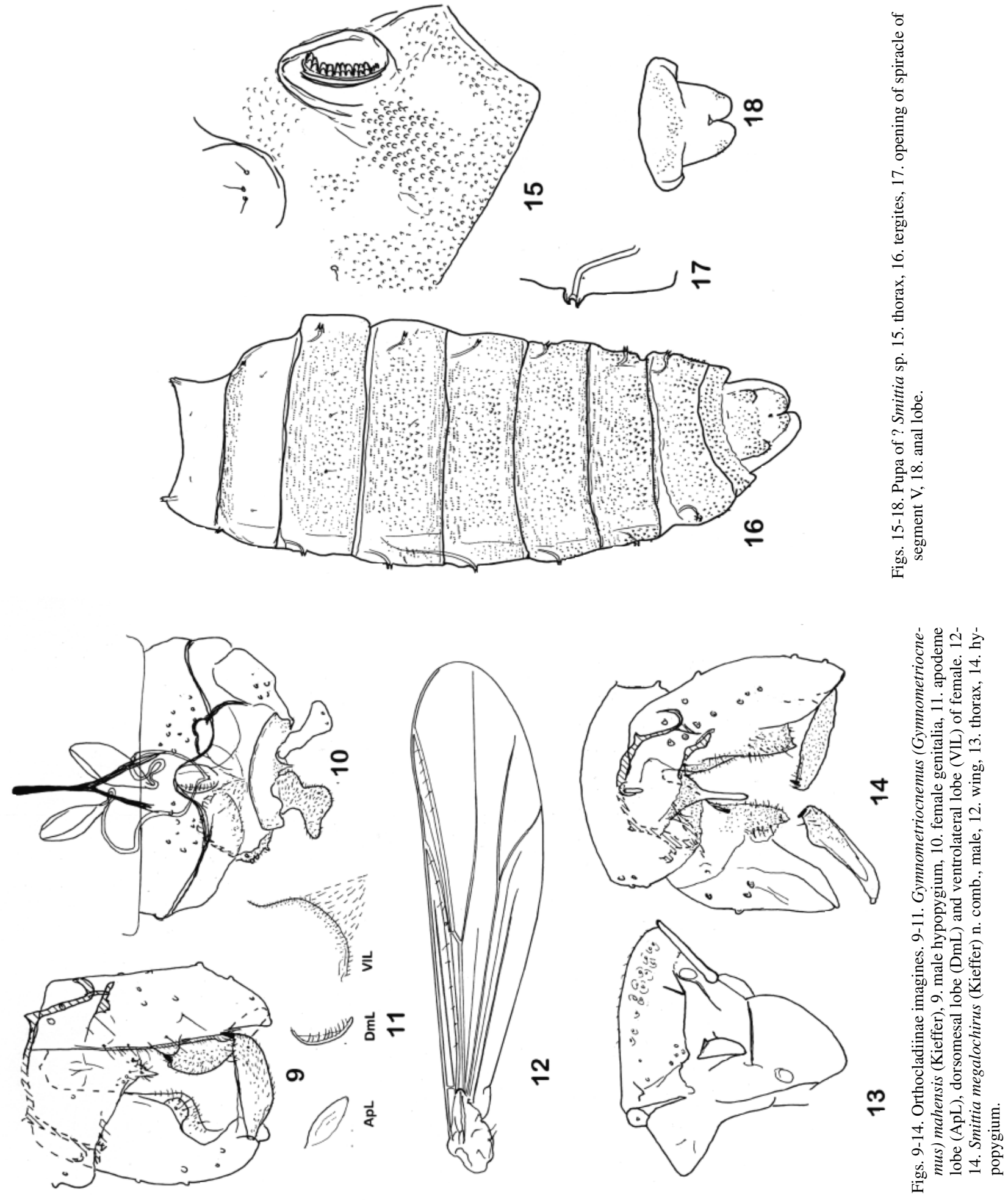


\section{Remarks}

The specimens are in a bad shape and some details such as the apparent presence of a true anal point may be misinterpreted. A virga was not observed, but the male specimen is much cleared and there may be a small virga. However, the species obviously cannot belong to the subgenus Rhaphidocladius Sæther.

\section{Distribution}

The species previously was known only from the female holotype from Mahé, Cascade Estate, 240-460 m a.s.l. Mon Plaisir on Silhouette is a high altitude forest with a highly diverse fauna and flora (Gerlach 2003).

\section{Corynoneura seychellensis Kieffer, nomen dubium \\ Corynoneura seychellensis Kieffer, 1911b : 363. \\ Corynoneura seychellensis Kieffer ; Freeman 1956 :} 364)

Corynoneura seychellensis Kieffer ; Freeman \& Cranston $1980: 182$.

According to Freeman (1956) the single male present of the type series is lacking the abdomen and thus must be regarded as a nomen dubium. No specimens of Corynoneura were present in the recent collections. The type locality of the species is Mahé, Cascade Estate, 800-1, 500 feet.

\section{Smittia megalochirus (Kieffer) comb. $\mathbf{n}$.}

(Figures 12-14)

Dactylocladius megalochirus Kieffer, 1911b : 363.

Orthocladius megalochirus (Kieffer) ; Freeman 1956 : 336, Freeman \& Cranston $1980: 184$.

Material examined : SEYCHELLES: Silhouette, Mon Plaisir, 6 O', 8 vii- 6 viii 2000, J. Gerlach (ZMBN); Mahé, Marc aux Cochons, 1 ơ, 29 viii 2002, J. Gerlach (ZMBN).

Diagnostic characters: The imago is distinguished by having completely bare eyes, weak acrostichals starting in front near antepronotum, two setae on squama and setae on $\mathrm{R}_{1}$ and $\mathrm{R}_{4+5}$.

\section{MALE IMAGO (n=6-7 except when otherwise sta- ted)}

Total length 1.80-2.02, $1.92 \mathrm{~mm}$. Wing length 1.01$1.13,1.04 \mathrm{~mm}$. Total length/wing length 1.73-1.92, 1.82. Wing length/length of profemur 2.00-2.24 (3). Coloration blackish brown

Head. Antenna lost. (AR 0.6 according to Freeman, 1956). Temporal setae 9-11 (3) ; consisting of 3-6, 5 (4) inner verticals ; 2-3 (3) outer verticals ; and 2-4, 3
(4) postorbitals. Clypeus with 8-13 (3) setae. Tentorium 98-113 $\mu \mathrm{m}(3)$ long, 21-23 $\mu \mathrm{m}$ (3) wide. Palpomere lengths (in $\mu \mathrm{m}): 23-26,25$ (4) ; 34-41, 38 (4) ; 71-90, 80 (4); 90-101 (2); and lost. Third palpomere with 2 (2) rather broad lanceolate sensilla clavata.

Thorax (Fig. 13). Antepronotum with 1-2 (3) setae. Dorsocentrals 14-16, 15; acrostichals $12-17,15$; prealars 4-5, 4 (4), supraalar 1 (3). Scutellum with 6-8, 7 setae.

Wing (Fig. 12). VR 1.36-1.54, 1.48. Costal extension 120-135, $128 \mu \mathrm{m}$ long. Brachiolum with 1seta; costal extension with 2-4, 3 non-marginal setae ; $\mathrm{R}$ with $7-11,8$ setae; $\mathrm{R}_{1}$ with $4-6,5 ; \mathrm{R}_{4+5}$ with $7-10,8$ setae; other veins bare. Squama with 2 setae.

Legs. Spur of front tibia $56 \mu \mathrm{m}$ (1) long ; spurs of middle tibia $30 \mu \mathrm{m}(1)$ and $19 \mu \mathrm{m}$ (1) long ; of hind tibia 45-60, $54 \mu \mathrm{m}(4)$ and $19 \mu \mathrm{m}$ (1) long. Width at apex of front and middle tibiae each 26-30, $29 \mu \mathrm{m}(4)$; of hind tibia 30-38, $33 \mu \mathrm{m}$. Comb of 9 (5) setae ; longest setae 38-41, $39 \mu \mathrm{m}$ (5) long ; shortest setae 23-26, $24 \mu \mathrm{m}$ (4) long. Tarsi lost on all legs. Lengths (in $\mu \mathrm{m}$ ) of front to hind femora : 482-567, 515 (4) ; 449-539, 485 ; 463-539, 492 ; of front to hind tibiae : 473-558, 511 (4) ; 397-539, 469 (5) ; 473-610, 537.

Hypopygium (Fig. 14). Anal point 45-56, $50 \mu \mathrm{m}(5)$ long. Tergite IX with 4-7, 6 setae; laterosternite IX with 5 setae. Phallapodeme 56-64, $58 \mu \mathrm{m}$ long; transverse sternapodeme $54-60,56 \mu \mathrm{m}$ long, oral projections normally developed. Virga $11 \mu \mathrm{m}$ (2) long. (It is not clear whether there are one broad single spine or a few separate spines.) Gonocoxite 143-154, $149 \mu \mathrm{m}$ long. Gonostylus 77-86, $81 \mu \mathrm{m}$ long; with 8-11, $9 \mu \mathrm{m}(5)$ long megaseta. HR 1.78-1.95, 1.84; HV 2.25-2.44, 2.36 .

\section{Remarks}

Based on the presence of setae on the squama Freeman (1956) placed the species in Orthocladius v. d. Wulp. The wing venation shown in Freeman (1956, fig. 9 d) is typical of Smittia Holmgren and cannot belong to an Orthocladius. However, there are several details that do not fit the generic diagnosis given in Cranston et al. (1989). Presence of minute acrostichals and completely bare eyes are not unique within Smittia Holmgren. The presence of setae on the squama and of setae on $R_{1}$ and $R_{4+5}$, however, appear to be unique and the species could well deserve a separate genus. The wing venation as well as the hypopygium, however, is typical for species belonging to Smittia. The vertical position of the anal point indicated by Freeman (1956 fig. 9 k) appears to be an artefact. 


\section{Distribution}

The species previously was known only from the male holotype from Mahé at the top of Mt. Sebert, 550 $\mathrm{m}$.

\section{? Smittia mahensis (Kieffer)}

Dactylocladius mahensis Kieffer : 1911b : 361

Smittia mahensis (Kieffer) ; Freeman 1956 : 353.

Pseudosmittia mahensis (Kieffer) ; Freeman \& Cranston 1980 : 186.

Material examined : SEYCHELLES : Silhouette, Mon Plaisir, 1 damaged O’, 8 vii- 6 viii 2000, J. Gerlach (ZMBN).

Diagnostic characters : The male imago is distinguished by having completely bare eyes, weak acrostichals starting in front near antepronotum and 1 seta on vein $\mathrm{R}$ with other veins bare.

MALE IMAGO $(n=1)$

Total length $1.80 \mathrm{~mm}$. Wing length $1.04 \mathrm{~mm}$. Total length/wing length 1.74 . Wing length/length of profemur 2.24.

Head. Antenna lost. (AR 0.9 in type according to Freeman.). Eyes completely bare. Temporal setae 9, consisting of 4 inner verticals, 2 outer verticals, and 3 postorbitals. Clypeus with 13 setae. Tentorium, stipes and palp not measurable.

Thorax. Antepronotum apparently with 2 setae. Dorsocentrals 6 , acrostichals about 12 , prealars 3 , supraalar 1. Scutellum with 6 setae.

Wing. Wing venation as in Smittia megalochirus. VR 1.46. Costa1 extension $135 \mu \mathrm{m}$ long. Brachiolum with 1 seta, $\mathrm{R}$ with 1 setae, other veins bare. Squama bare.

Legs. Spur of front tibia $41 \mu \mathrm{m}$ long, spurs of middle tibia $23 \mu \mathrm{m}$ and $19 \mu \mathrm{m}$ long, of hind tibia $41 \mu \mathrm{m}$ and $15 \mu \mathrm{m}$ long. Width at apex of front tibia $24 \mu \mathrm{m}$, of middle tibia $28 \mu \mathrm{m}$, of hind tibia $34 \mu \mathrm{m}$. Comb of 10 setae, 19-34 $\mu \mathrm{m}$ long. Lengths (in $\mu \mathrm{m}$ ) of front to hind femora : 463, 463, 510 ; of front to hind tibiae : 520 , 439, 553. All tarsi lost.

Hypopygium. Laterosternite IX with 6 setae. Transverse sternapodeme $49 \mu \mathrm{m}$ long. Gonocoxite $114 \mu \mathrm{m}$ long. Gonostylus $53 \mu \mathrm{m}$ long, evenly wide. HR 2.14, HV 3.41. Other details not measurable.

\section{Remarks}

The type of Smittia mahensis from Mahé is damaged and lacks the hypopygium, but there are short acrostichals starting in front of the scutum. Although both specimens described here and the holotype are damaged it should be possible to recognise the species based on the completely bare eyes, the presence of several acrostichals and the single seta on vein $R$.

\section{Distribution}

The species is known only from Mahé and Silhouette.

\section{? Smittia Holmgren}

(Figures 15-18)

Material examined : SEYCHELLES : Silhouette, Corgat-Cocos Marrons Ridge, litter, pupal exuviae, 18 viii 2000, J. Gerlach (ZMBN).

A very interesting pupa with well developed thoracic and abdominal spiracles is illustrated in figures 1518. No hemipneustic chironomid pupa is previously known, all either are propneustic or apneustic. The pupa conceivably could belong to a different family such as the Ceratopogonidae, but keys to Smittia both in Coffman et al. (1986) and Sæther et al. (2000)

The pupa is $2.16 \mathrm{~mm}$ long. All thoracic setae are 15 $\mu \mathrm{m}$ long or shorter. The anterior spiracle opening (Fig. 15) consists of an oval area $71 \mu \mathrm{m}$ long and $38 \mu \mathrm{m}$ wide, with about 10 tubercles along one side. The distance from the anterior dorsocentral $\left(\mathrm{Dc}_{1}\right)$ to the second is $79 \mu \mathrm{m}$, from $\mathrm{Dc}_{2}$ to $\mathrm{Dc}_{3} 4 \mathrm{~mm}$, from $\mathrm{Dc}_{3}$ to $\mathrm{Dc}_{4} 11$ $\mathrm{mm}$.

\section{Clunio gerlachi sp. n.}

(Figures 19-26)

Material examined : Holotype : ơ, SEYCHELLES: Silhouette, La Passe (above Dauban mausoleum), Malaise, 1-4 vii 2000, J. Gerlach (ZMBN Type No.403). Paratypes, as holotype, 23 o', 1 우 in copula with holotype, 1-4 vii 2000, J. Gerlach (ZMBN, UMZC, BMNH); Silhouette, La Passe, Heath trap, 18 ơ, 12 viii 2000, J. Gerlach (ZMBN, UMZC, BMNH).

Etymology: Named after the collector of the material from the Seychelles and the initiator of the expedition.

Diagnostic characters: The male imago is distinguished by an antenna with 9 flagellomeres with ultimate flagellomere as long as the 6-7 preceding, scutellum with about 12-14 setae in double row, tibial spurs strongly curved, third tarsomere of hind leg deeply incised and tergite IX with 1-6 setae. The female has only about 8 ommatidia and 4 flagellomeres.

MALE IMAGO (n=10 except when otherwise stated) 
Total length 2.49-2.72, $2.62 \mathrm{~mm}$ (4). Wing length $1.20-1.46,1.30 \mathrm{~mm}$. Total length/wing length 1.902.20,2.65 (4). Wing length/length of profemur 3.23$3.49,3.33$. Coloration pale brown with hypopygium darker.

Head. Eyes hairy. Antenna (Fig. 20) with 9 flagellomeres, ultimate flagellomere as long as 6-7 preceding flagellomeres, basal flagellomere 0.63-0.90, 0.78 times as long as ultimate. AR 0.46-0.67, 0.54. Lengths (in $\mu \mathrm{m}$ ) of flagellomeres : 120-150, 136; 30-38, 34 ; 28-38, 31 ; 19-30, 28 ; 19-30, 27 ; 17-28, 26 ; 17-30, 25 ; 23-26, 24 ; 154-233, 178. No temporal setae. Clypeus with $0-1,0$ setae. Tentorium 45-64, $53 \mu \mathrm{m}$ long ; 9-11, $10 \mu \mathrm{m}$ wide. Basal palpomere 11-26, $16 \mu \mathrm{m}$ long; second palpomere 45-60, $53 \mu \mathrm{m}$ long.

Thorax. Dorsocentrals 3-8, 5 ; acrostichals very weak, about 3-6, 5 ; prealars 2-5, 3. Scutellum with 1214,13 setae in two irregular transverse rows.

Wing (Fig. 19). VR 1.29-1.40, 1.35. R with 1-3, 2 setae $; \mathrm{R}_{1}$ with $1-2,2 ; \mathrm{R}_{4+5}$ with $1-5,3$ setae ; other veins bare.

Legs. Spur of front tibia 19-30, $27 \mu \mathrm{m}$ long ; spurs of middle tibia 28-41, $36 \mu \mathrm{m}$ and 11-19, $15 \mu \mathrm{m}$ (7) long, second spur perhaps sometimes absent ; of hind tibia 41-56, $47 \mu \mathrm{m}$ and 15-26, $18 \mu \mathrm{m}$ long ; all longer spurs strongly curved at apex. Width at apex of front tibia $38-49,44 \mu \mathrm{m}$; of middle tibia $45-56,51 \mu \mathrm{m}$; of hind tibia $49-60,56 \mu \mathrm{m}$. Lengths and proportions of legs as in Table 1.

Hypopygium (Fig. 21). Tergite IX with 1-6, 3 setae ; laterosternite bare. Gonocoxite 476-563, $515 \mu \mathrm{m}$ long; with about 6-10 setae on inner apical margin. Gonostylus 229-270, $252 \mu \mathrm{m}$ long ; with 5-10, 7 apical spines ; 4-11, 6 to 15-26, $20 \mu \mathrm{m}$ long ; inner fold also with 2-4 weak spines at anterior apex. HR 1.97-2.14, 12.05 ; HV1.01-1.08, 1.05 (4), 2.36.

FEMALE IMAGO $(n=1-2)$

Total length about $1.7 \mathrm{~mm}$.

Head. Antenna (Fig. 23) with 4 flagellomeres, AR 0.71. Lengths (in $\mu \mathrm{m}$ ) of flagellomeres: 19, 19, 15, 38 .
Eye (Fig. 24) with about 8 ommatids. Other details not clear.

Legs. All leg segments apparently of similar lengths. Lengths (in $\mu \mathrm{m}$ ) femur to $\mathrm{ta}_{5}$ of each leg: $150,114-$ 116. 30-34, 19-23, 19, 19, 26-30. LR $_{3}$ 0.24-0.29.

Genitalia (Figs 25-26). Gonocoxite apparently a few short setae. Seminal capsule $75 \mu \mathrm{m}$ long. Notum $90 \mu \mathrm{m}$ long. Other details not measurable.

\section{Remarks}

The genus Clunio Haliday is in need of revision. However, $C$. gerlachi differs from $C$. pacificus Edwards by having hairy eyes and strongly curved tibial spur ; from C. tuthilli Tokunaga (Tokunaga 1964 : 537) by having ultimate flagellomere as long as the 6-7 preceding segments and an apparent different aedeagus; from $C$. marinus Haliday by the strongly incised third tarsomere on the hind leg, the strongly curved tibial spurs, more numerous setae on the scutellum and by having ultimate flagellomere as long as the 6-7 preceding segments. However, according to Edwards (1926 fig. 2a) there are 9 flagellomeres in $C$. marinus while Tokunaga (1964 : 537) mentions 10 flagellomeres indicating that they have different species. Some specimens from Gough Island in the Atlantic apparently belonging to C. africanus Hesse have been compared with $C$. gerlachi. They resemble $C$. gerlachi in the tibial spur, the third tarsomere of the hind leg as well as the shape of the aedeagus. However, the ultimate flagellomere is only as long as the 4-5 preceding flagellomeres, scutellum has 16-22 multiserial setae, tergite IX carries 2-17 setae and the gonostylus is more similar to that of $C$. marinus as for instance illustrated by Strenzke (1960 fig.11). The female of C. gerlachi differs from that of $C$. marinus by having only about 8 ommatidia in the eye and 4 flagellomeres as in C. pacificus (Tokunaga 1935), while $C$. marinus has 21-31 ommatidia and 5 flagellomeres and $C$. tsushimensis Tokunaga has about 14 ommatidia and 4 flagellomeres (Tokunaga 1935). C. pacificus may be the closest related species of $C$. gerlachi.

Table 1. Clunio gerlachi sp. n. Length (in $\mu \mathrm{m}$ ) and proportions of legs of males.

\begin{tabular}{lllllll}
\hline & $\mathrm{fe}$ & $\mathbf{t}$ & $\mathrm{ta}_{1}$ & $\mathrm{ta}_{2}$ & $\mathrm{ta}_{3}$ & $\mathrm{ta}_{4}$ \\
\hline $\mathrm{p}_{1}$ & $369-425,394$ & $572-680,622$ & $95-123,111$ & $28-47,41$ & $28-38,32$ & $24-28,26$ \\
$\mathrm{p}_{2}$ & $482-572,532$ & $425-539,483$ & $76-85,83$ & $28-43,37$ & $28-38,33$ & $24-28,26$ \\
$\mathrm{p}_{3}$ & $510-614,554$ & $491-572,518$ & $85-99,93$ & $28-38,37$ & $57-76,64$ & $24-28,28$ \\
& $\mathrm{ta}_{5}$ & $\mathrm{LR}$ & $\mathrm{BV}$ & $\mathrm{SV}$ & $\mathrm{BR}$ & \\
$\mathrm{p}_{1}$ & $33-47,41$ & $0.16-0.20,0.18$ & $7.45-9.48,8.11$ & $8.25-10.98,9.26$ & $0.8-1.0,1.0$ & \\
$\mathrm{p}_{2}$ & $38-47,42$ & $0.16-0.19,0.17$ & $7.36-8.64,7.95$ & $9.22-12.82,11.85$ & $1.0-1.6,1.2$ & \\
$\mathrm{p}_{3}$ & $38-52,43$ & $0.16-0.20,0.18$ & $6.29-7.74,6.81$ & $10.19-12.78,11.58$ & $1.6-2.7,2.1$ & \\
\hline
\end{tabular}




\section{Distribution}

The species is known only from La Passe, Silhouette, the main settlement area of the island (Gerlach 2003).

\section{Semiocladius brevicornis (Tokunaga)}

Smittia brevicornis Tokunaga, 1964 : 518.

Semiocladius brevicornis (Tokunaga) ; Cranston \& Martin $1989: 263$.

Semiocladius brevicornis (Tokunaga) ; Sæther \& Ferrington 1997 : 229.

Material examined : SEYCHELLES : Silhouette, La Passe, Heath trap, 9 o', 12 viii 2000, J. Gerlach (ZMBN, UMZC, BMNH).

The species previously was known only from Micronesia (Caroline Is.) (Tokunaga 1964 as Smittia). Sæther \& Ferrington (1997) redescribed the species.

\section{Pseudosmittia triangula (Tokunaga)}

(Figures 29-30)

Smittia triangula Tokunaga, 1964: 524.

Pseudosmittia triangula (Tokunaga); Cranston \& Martin 1989: 262.

Material examined : SEYCHELLES : SEYCHELLES : Silhouette, Grand Barbe, 4 O’, 6 i 2002, J. Gerlach; Silhouette, La Passe (above Dauban mausoleum), Malaise, 1 ơ, 1-4 vii 2000, J. Gerlach (ZMBN).

The species previously was known from Caroline and Marshall Islands (Tokunaga 1964 as Smittia). The type has been examined in connection with an ongoing revision of the genus Pseudosmittia. The coastal woodland and marsh at Grande Barbe is an extremely rich environment and one of the most important marsh habitats in the Seychelles (Gerlach 2003).

\section{Pseudosmittia melanostola (Kieffer)}

(Figures 27, 31)

Dactylocladius melanostolus Kieffer, 1911b : 362.

Smittia melanostola (Kieffer) ; Freeman 1956 : 357, pro parte.

Pseudosmittia melanostola (Kieffer) ; Freeman \& Cranston 1980 : 186 pro parte.
Material examined : SEYCHELLES : Mahé, Cascade Estate, lectotype o', here designated, iii 1909, J. S. Gardineau (BMNH); Mahé, Marc aux Cochons, 1 o', 29 viii 2002, J. Gerlach (ZMBN),

Diagnostic characters : The long, bare, parallel-sided anal point combined with the forked postcubitus and $\mathrm{R}_{4+5}$ ending above apex of $\mathrm{M}_{3+4}$ separate this species from other members of the genus.

\section{MALE IMAGO $(n=1-2)$}

Total length 2.22-2.40 mm. Wing length 1.30-1.31 $\mathrm{mm}$. Total length/wing length 1.70-1.84. Wing length/length of profemur 2.42. Coloration black, according to Freeman (1956) with brilliant silvery pruinose shoulders.

Head. AR 1.39. Ultimate flagellomere $414 \mu \mathrm{m}$ long. Temporal setae 10-11, consisting of 5-6 inner verticals, 5 outer verticals, no postorbitals. Clypeus with 9-11 setae. Tentorium 113-130 $\mu \mathrm{m}$ long, 23-25 $\mu \mathrm{m}$ wide. Stipes 105-118 $\mu \mathrm{m}$ long, $46 \mu \mathrm{m}$ wide. Palpomere lengths (in $\mu \mathrm{m}$ ) : 27-24, 34-41, 85, 89, 129. Third palpomere with 15 scalpellate sensilla clavata.

Thorax. Median antepronotal lobes slightly reduced, antepronotum with 4-8 lateral setae. Dorsocentrals 24, acrostichals 2, prealars 6-9, no supraalar seta. Scutellum with 12-14 setae.

Wing (Fig. 27). VR 1.54-1.56. VR 2 1.25-1.26. Anal lobe present. Costal extension $62-79 \mu \mathrm{m}$ long. $\mathrm{R}_{4+5}$ ending above apex of $\mathrm{M}_{3+4} ; \mathrm{Cu}_{1}$ curved. Brachiolum with 1 seta, $R$ with 11-12 setae, $R_{1}$ with $1-3$ setae, other veins bare.

Legs. Spur of front tibia $53 \mu \mathrm{m}$ long, spurs of middle tibia $41 \mu \mathrm{m}$ and $27 \mu \mathrm{m}$ long, of hind tibia $62 \mu \mathrm{m}$ and $32 \mu \mathrm{m}$ long. Width at apex of front and middle tibiae each 29-30 $\mu \mathrm{m}$, of hind tibia 37-39 $\mu \mathrm{m}$. Comb of 10-11 setae, $20-46 \mu \mathrm{m}$ long. Lengths and proportions of legs as in Table 2.

Hypopygium (Fig. 31, Freeman 1956 fig. 14k). Anal point $57 \mu \mathrm{m}$ long, parallel-sided and bare ; tergite IX with 9-10 weak setae ; laterosternite IX with 4-5 setae. Phallapodeme $75 \mu \mathrm{m}$ long ; transverse sternapodeme about 56-59 $\mu \mathrm{m}$ long, no oral projections. Virga 23$26 \mu \mathrm{m}$ long. Gonocoxite $188-190 \mu \mathrm{m}$ long; no superior

Table 2. Pseudosmittia melanostola (Kieffer). Length (in $\mu \mathrm{m}$ ) and proportions of legs of males.

\begin{tabular}{lllllllllll}
\hline & $\mathrm{fe}$ & $\mathrm{ti}$ & $\mathrm{ta}_{1}$ & $\mathrm{ta}_{2}$ & $\mathrm{ta}_{3}$ & $\mathrm{ta}_{4}$ & $\mathrm{ta}_{5}$ & $\mathrm{LR}$ & $\mathrm{BV}$ & $\mathrm{SV}$ \\
\hline $\mathrm{p}_{1}$ & 540 & 540 & 347 & 203 & 171 & 104 & 63 & 0.64 & 2.64 & 3.12 \\
$\mathrm{p}_{2}$ & $585-614$ & $576-610$ & 324 & 162 & 126 & 77 & 54 & 0.56 & 3.55 & 3.58 \\
$\mathrm{p}_{3}$ & $585-605$ & $594-652$ & 387 & 216 & 180 & 90 & 54 & 0.66 & 2.90 & 3.05 \\
\hline
\end{tabular}



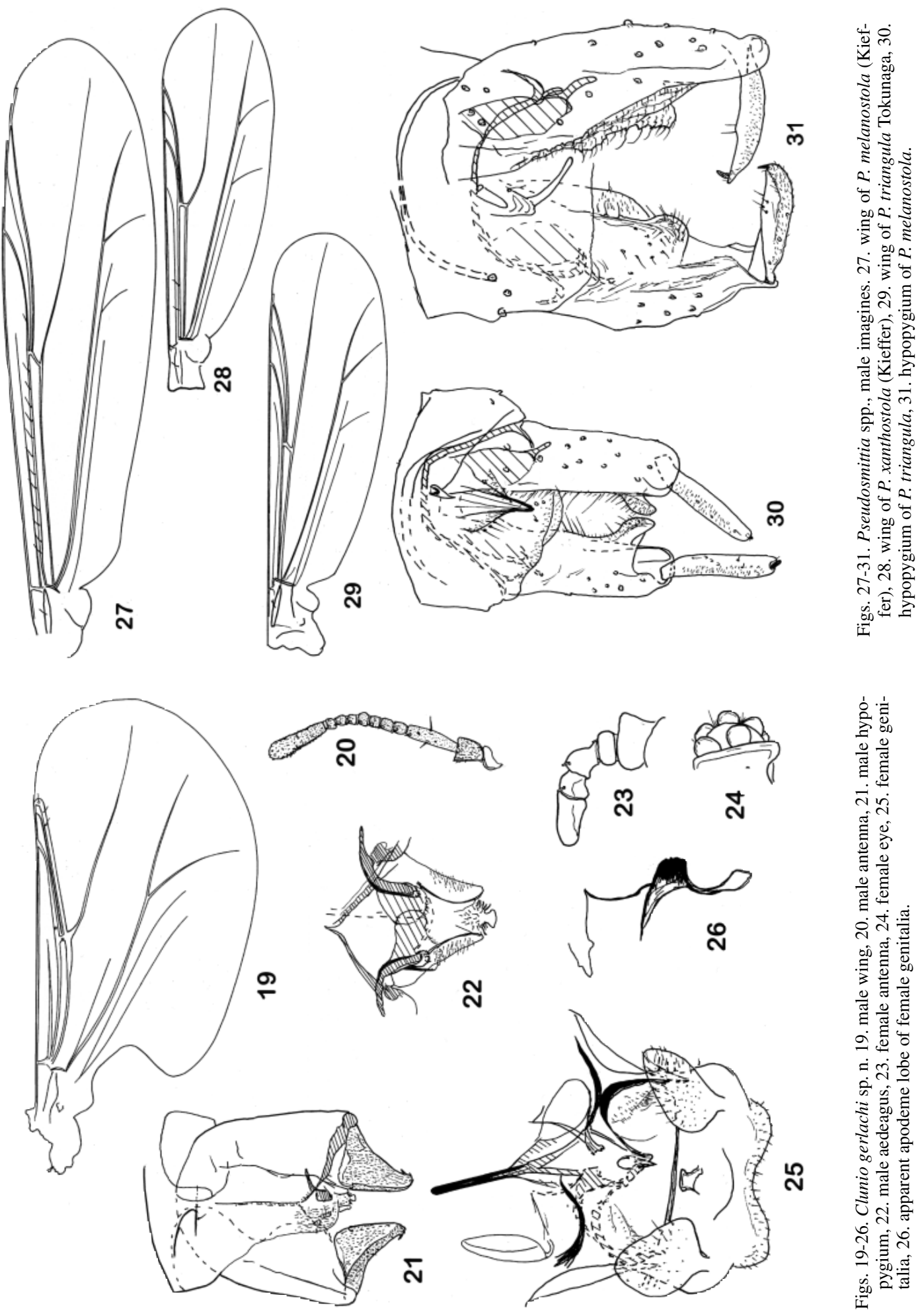
volsella; inferior volsella reaching to $0.68-0.70$ gonocoxite length, no accessory lobe. Gonostylus $73 \mu \mathrm{m}$ long, megaseta $7 \mu \mathrm{m}$ long; HR 2.59-2.73, HV 2.963.05 .

\section{Remarks}

Freeman synonymized Dactylocladius melanostolus with Dactylocladius xanthostolus and D. heterostolus. The types of $P$. xanthostolus have been examined. The wing venation is quite different and the size considerably smaller. P. melanostola appear related to P. macrobrachia (Edwards) from Samoa (Edwards 1928: 62).

\section{Distribution}

This species is known only from the Seychelles.

\section{Pseudosmittia xanthostola (Kieffer)}

(Figures 28, 32-36)

Dactylocladius xanthostolus Kieffer, 1911b : 362.

Dactylocladius heterostolus Kieffer, 1911b : 363.

Smittia melanostola (Kieffer) ; Freeman 1956 : 357, pro parte.

Pseudosmittia melanostola (Kieffer) ; Freeman \& Cranston 1980 : 186, pro parte.

Material examined : SEYCHELLES : Mahé, Cascade Estate, lectotype , here designated, iii 1909, J. S. Gardiner (BMNH); 2 ㅇ paralectotypes, same data as lectotype; Mahé, Anse aux Pins, mangrove, 1 o', 19 xii 1992, H. Malicky (ZSM); Anonyme Island, lectotype of heterostolus , here designated, I 1909, J. S. Gardiner $(\mathrm{BMNH})$.

Diagnostic characters : The imagines are characterised by having a strong apical antennal seta in both sexes, 12-14 scalpellate sensilla clavata located subapically on the third palpomere, postcubitus forked in both sexes, 16-20 dorsocentrals and 9-15 setae on the clypeus. The male imago is easily recognised by the sharply triangular large and dark anal point and the extremely long digitiform inferior volsella. The female can be separated from the very similar females of Pseudosmittia brevifurcata by having a distinct postcubital fork and only a posterior group of 5-6 prealar setae in addition to being smaller in size.

$$
\text { MALE IMAGO }(n=1)
$$

Total length $1.64 \mathrm{~mm}$. Wing length $0.82 \mathrm{~mm}$. Total length/wing length 1.99. Wing length/length of profemur 2.61. Coloration blackish brown.

Head. AR 0.45. Ultimate flagellomere $155 \mu \mathrm{m}$ long, with $39 \mu \mathrm{m}$ long strong apical seta. Temporal setae 5, consisting of 2 inner verticals and 3 outer verticals, no postorbitals. Clypeus with 9 setae. Tentorium $107 \mu \mathrm{m}$ long, $16 \mu \mathrm{m}$ wide. Palpomere lengths (in $\mu \mathrm{m}$ ) : 22, 27, $50,57,97$. Third palpomere with about 12 strongly scalpellate sensilla clavata.

Thorax. Antepronotal lobes not observable. Dorsocentrals 17 , acrostichals 2 , apparently 6 prealars, no supraalar seta. Scutellum with 6 setae.

Wing (Fig. 28). VR 1.63, VR 2 1.26. Anal lobe reduced, but wing not cuneiform. Costa not extended. $\mathrm{R}_{4+5}$ ending well proximal to apex of $\mathrm{M}_{3+4} ; \mathrm{Cu}_{1}$ slightly curved. Brachiolum with 1 seta, $\mathrm{R}$ with 2 setae, other veins bare.

Legs. Spur of front tibia $37 \mu \mathrm{m}$ long, single spur of middle tibia $21 \mu \mathrm{m}$ long, of hind tibia $37 \mu \mathrm{m}$ and $18 \mu \mathrm{m}$ long. Width at apex of front and middle tibiae each 21 $22 \mu \mathrm{m}$, of hind tibia $34 \mu \mathrm{m}$. Comb of 16 setae, 25-32 $\mu \mathrm{m}$ long. Lengths and proportions of legs as in Table 3.

Hypopygium (Fig. 32). Anal point $54 \mu \mathrm{m}$ long, $46 \mu \mathrm{m}$ wide at base, sharply triangular and with 10 lateral setae; laterosternite ix with 4 setae. Phallapodeme $50 \mu \mathrm{m}$ long ; transverse sternapodeme $37 \mu \mathrm{m}$ long, no oral projections. Virga $14 \mu \mathrm{m}$ long. Gonocoxite $112 \mu \mathrm{m}$ long, with $56 \mu \mathrm{m}$ long digitiform inferior volsella placed proximally on gonostylus but reaching to 0.82 gonocoxite length. Gonostylus $75 \mu \mathrm{m}$ long ; attenuate, with $8 \mu \mathrm{m}$ long megaseta pointing in longitudinal direction. HR 1.48, HV 2.19.

FEMALE IMAGO (n=3-4, except when otherwise stated)

Total length 1.59-1.77. Wing length 0.76-0.83. Total length/wing length 1.96-2.11 (2). Wing length/length of profemur 2.33-2.45 (2). Coloration blackish brown.

Table 3. Pseudosmittia xanthostola (Kieffer). Length (in $\mu \mathrm{m}$ ) and proportions of legs of males.

\begin{tabular}{llllllllllll}
\hline & $\mathrm{fe}$ & $\mathrm{ti}$ & $\mathrm{ta}_{1}$ & $\mathrm{ta}_{2}$ & $\mathrm{ta}_{3}$ & $\mathrm{ta}_{4}$ & $\mathrm{ta}_{5}$ & LR & BV & SV & BR \\
\hline $\mathrm{p}_{1}$ & 315 & 356 & 180 & $\mathbf{8 1}$ & 63 & 41 & 41 & 0.51 & 3.78 & 3.73 & 2.4 \\
$\mathrm{p}_{2}$ & 351 & 360 & 185 & 90 & 68 & 41 & 36 & 0.53 & 3.85 & 3.76 & 3.2 \\
$\mathrm{p}_{3}$ & 351 & 360 & 230 & 117 & 108 & 50 & 41 & 0.64 & 3.03 & 3.10 & 3.8 \\
\hline
\end{tabular}


Head. AR 0.54-0.55 (2). Lengths of flagellomeres (in $\mu \mathrm{m}$ ) 53-59, 37-43, 41-46, 41-46, 91-96 (2). Ultimate flagellomere with lost strong apical seta. Temporal setae 5-10, 8, consisting of 3-5, 4 inner verticals and 26,4 outer verticals, no postorbitals. Clypeus with 1115, 13 setae. Tentorium 101-105, $104 \mu \mathrm{m}$ long, 7-11, 9 $\mu \mathrm{m}$ wide. Stipes 87-91, $90 \mu \mathrm{m}$ long, 23-30, $26 \mu \mathrm{m}$ wide. Palpomere lengths (in $\mu \mathrm{m}$ ) : 21-30, 24; 27-30, 29; 57-69; 69-72 (2); 105-112 (2). Third palpomere with 13-14 (2) scalpellate sensilla clavata. Coronal suture complete in 3 specimens, $34 \mu \mathrm{m}$ long in fourth specimen.

Thorax. Median antepronotal lobes reduced, antepronotum with 2-3, 3 lateral setae. Dorsocentrals 1620, 17 ; acrostichals 2 ; prealars 5-6, 5 ; no supraalar seta. Scutellum with 6-8, 8 setae.

Wing. VR 1.62-1.76, VR 2 1.37-1.48. Costal extension 87-105 $\mu \mathrm{m}$ long. $\mathrm{R}_{4+5}$ ending well proximal to apex of $\mathrm{M}_{3+4} ; \mathrm{Cu}_{1}$ straight. Brachiolum with 1seta, costal extension with 7-13 non-marginal setae, $\mathrm{R}$ with 6-9 setae, $R_{1}$ with $2, R_{4+5}$ with 9-11 setae, other veins bare.

Legs. Spur of front tibia $32 \mu \mathrm{m}$ long, spur of middle lost, of hind tibia 46-48 $\mu \mathrm{m}$ (2) and $22 \mu \mathrm{m}$ (1) long. Width at apex of front and middle tibiae each 23$25 \mu \mathrm{m}$, of hind tibia 34-48 $\mu \mathrm{m}$. Comb of 14-15 setae, 26-43 $\mu \mathrm{m}$ long. Tarsi lost on all front and middle legs. Lengths (in $\mu \mathrm{m}$ ) of front to hind femora: 324-332 ; $351-414$ (2) ; 342-414; of front to hind tibiae : 351$365(2) ; 396(1) ; 374-432$; of hind $\mathrm{ta}_{1}-\mathrm{ta}_{5} 243 ; 108$; $113 ; 45 ; 36 . \mathrm{LR}_{3} 0.57$ (1), $\mathrm{BV}_{3} 3.58$ (1), $\mathrm{SV}_{3} 3.44$ (1), $\mathrm{BR}_{3} 2.7$ (1).

Abdomen. Tergite I bare ; T II-V each with 18-25, 21 setae ; T VI with 14-21, 16 ; T VII with 11-17, 15 ; T VIII with 12-16, 14 setae. Sternites I and II bare ; S III with 4-6 setae ; S IV-VI each with 6-11, 8 ; S VII with $8-17,12$; S VIII with 29-34, 32 setae.

Genitalia (Figs 32-36). Gonocoxite with 1-2, 2 strong and 2-3, 2 weak setae. Tergite IX divided; with altogether 9-11, 11 setae ; apodeme against gonocoxite 75-85, $81 \mu \mathrm{m}$ long. Cercus 59-69, $65 \mu \mathrm{m}$ long. Seminal capsule relatively pale, 69-71, $70 \mu \mathrm{m}$ long ; 46$59 \mu \mathrm{m}$ wide ; apparently no microtrichiae. Notum 80$89,83 \mu \mathrm{m}$ long.

\section{Remarks}

Freeman (1956 : 357) synonymized Pseudosmittia xanthostola and P. heterostola with P. melanostola. However, as shown above, $P$. melanostola cannot constitute the male of $P$. xanthostola. The present male, however, collected 83 years later, but on the same island, almost certainly is the male of $P$. xanthostola as deduced by sensilla clavata, numerous dorsocentrals, setae of the clypeus, and wing venation. P. xanthostola my be the sister species of the very similar $P$. bifurcata (Tokunaga) (Tokunaga, 1936 fig.1) known from Kiribati and Japan.

\section{Ecology and distribution}

The species has been collected from seaweed and in a mangrove area, and larvae are likely to live in the intertidal zone. According to Gerlach (2003) Anonyme Island has a small fresh-water fauna present in temporary pools of rain-water which could be an additional locality. The species is known only from the Seychelles.

\section{Pseudosmittia remigula sp. $\mathbf{n}$.}

\section{(Figure 37)}

Type material: Holotype : ơ, SEYCHELLES : Mahé, Marc aux Cochons, 29 viii 2002, J. Gerlach (ZMBN Type No.404). Paratype : 1 o', SEYCHELLES : no other data (BMNH).

Diagnostic characters : The absence of an anal point, the long adpressed inferior volsella with a covered accessory lobe, and particularly the paddle-oar-shaped gonostylus readily separate the male imago from other species of the genus.

Etymology : From the Latin remigulus, a rower, referring to the oar-shaped gonostyli.

\section{MALE IMAGO $(n=1-2)$}

Total length 1.92-2.12 mm. Wing length 1.05-1.15 $\mathrm{mm}$. Total length/wing length 1.83-1.84. Wing length/length of profemur 2.42-2.58. Coloration black.

Head. AR 1.15-1.33. Ultimate flagellomere 323$347 \mu \mathrm{m}$ long. Temporal setae 5, consisting of 2 inner verticals and 3 outer verticals, no postorbitals. Clypeus with 8-9 setae. Tentorium 113-119 $\mu \mathrm{m}$ long, 21-23 $\mu \mathrm{m}$ wide. Stipes 101-114 $\mu \mathrm{m}$ long, $23 \mu \mathrm{m}$ wide. Palpomere lengths (in $\mu \mathrm{m}$ ) : 26-30, 34-37, 71-78, 99-103, 124144. Third palpomere with $26-27 \mu \mathrm{m}$ long spine at apex, no sensilla clavata.

Thorax. Median antepronotal lobes reduced, antepronotum with 6-7 lateral setae. Dorsocentrals 12-16, acrostichals 2, prealars 3-5, and no supraalar seta. Scutellum with 9 setae.

Wing. VR 1.56-1.59, $\mathrm{VR}_{2}$ 1.25. Anal lobe relatively well developed. Costal extension $38 \mu \mathrm{m}$ long. $\mathrm{R}_{4+5}$ ending above apex of $\mathrm{M}_{3+4} ; \mathrm{Cu}_{1}$ nearly straight. Brachiolum with 1 seta, other veins bare.

Legs. Spur of front tibia 40-41 $\mu \mathrm{m}$ long, of middle ti- 
Table 4. Pseudosmittia remigula sp. $\mathrm{n}$. Length (in $\mu \mathrm{m}$ ) and proportions of legs of males.

\begin{tabular}{llllllllllll}
\hline & $\mathrm{fe}$ & $\mathrm{ti}$ & $\mathrm{ta}_{1}$ & $\mathrm{ta}_{2}$ & $\mathrm{ta}_{3}$ & $\mathrm{ta}_{4}$ & $\mathrm{ta}_{5}$ & $\mathrm{LR}$ & $\mathrm{BV}$ & $\mathrm{SV}$ & $\mathrm{BR}$ \\
\hline $\mathrm{p}_{1}$ & $406-468$ & $449-513$ & 252 & 144 & 108 & 72 & 54 & 0.49 & 3.29 & 3.93 & 2.6 \\
$\mathrm{p}_{2}$ & $473-540$ & $454-531$ & 279 & 149 & 113 & $\mathbf{8 1}$ & 50 & 0.53 & 3.45 & 3.84 & 2.6 \\
$\mathrm{p}_{3}$ & $477-522$ & $482-549$ & 324 & 176 & 167 & 86 & 54 & 0.59 & 2.90 & 3.31 & 4.0 \\
\hline
\end{tabular}

bia 28-31 $\mu \mathrm{m}$ long (only one spur), of hind tibia 50$56 \mu \mathrm{m}$ and $30 \mu \mathrm{m}$ long. Width at apex of front tibia 26$30 \mu \mathrm{m}$, of middle tibia $28-31 \mu \mathrm{m}$, of hind tibia $38-$ $43 \mu \mathrm{m}$. Comb of 11 setae, $23-39 \mu \mathrm{m}$ long. Lengths (in $\mu \mathrm{m}$ ) and proportions of legs as in Table 4.

Hypopygium (Fig. 37). Anal point absent; tergite IX with 11-16 weak setae; laterosternite IX with 7 setae. Phallapodeme 90-105 $\mu \mathrm{m}$ long; transverse sternapodeme 49-55 $\mu \mathrm{m}$ long, no oral projections. Virga 16$23 \mu \mathrm{m}$ long. Gonocoxite 154-162 $\mu \mathrm{m}$ long ; inferior volsella long, reaching to $0.79-0.88$ gonocoxite length. Gonostylus 124-135 $\mu \mathrm{m}$ long. HR 1.22-1.24, HV 1.551.59 .

\section{Remarks}

This highly peculiar species nonetheless has several synapomorphies in common with some species such as Pseudosmittia yapensis (Tokunaga) described by Tokunaga (1964) from Micronesia and P. brachydicrana (Edwards) (syn. P. micronesiana (Tokunaga)) known from Micronesia, Marshall Islands, Diego Garcia, Hawaii and Jamaica. The more important synapomorphies are shape of the inferior lobe and the absence of an anal point.

\section{Distribution}

The species is known only from the Seychelles.

\section{Subfamily Chironominae}

\section{Tanytarsus esakii Tokunaga}

(Figures 38-41)

Tanytarsus esakii Tokunaga, $1940: 224$.

Tanytarsus (Tanytarsus) esakii Tokunaga ; Tokunaga $1964: 622$.

Tanytarsus esakii Tokunaga ; Cranston \& Martin $1989: 266$.

Material examined : SEYCHELLES : Silhouette, La Passe, heath trap, 12 ơ, 4 \%, 12 viii 2000, J. Gerlach (ZMBN, UMZC, BMNH); Silhouette, Corgat-Cocos Marrons Ridge, litter, 5 o, 18 viii 2000, J. Gerlach
(ZMBN); Alphonse Island, Malaise and light, 15 ơ, 7 iv 2001, J. Gerlach (ZMBN); North Island, Calophyllum woodland, Malaise, 2 o', 30 vii- 1 viii 2002, J. Gerlach (ZMBN).

This very characteristic species was previously known from the Caroline and Marshall Islands. The species belongs to the T. «maritimus » group, which morphologically differ considerably from other members of the genus.

While all the other islands with records of chironomids are of granitic origin, Alphonse Island is coralline.

\section{Tanytarsus pallidissimus Kieffer}

Tanytarsus pallidissimus Kieffer, 1911b : 358.

Tanytarsus (Tanytarsus) pallidissimus Kieffer ; Freeman $1958: 338$.

Tanytarsus pallidissimus Kieffer ; Freeman \& Cranston 1980 : 201, Ekrem 2001 : 27.

The species is known only from Mahé in the Seychelles.

\section{Tanytarsus sp. n. near pallidissimus Kieffer}

(Figures 42-43)

Material examined : SEYCHELLES : Mahé, Marc aux Cochons, 1 ơ, 29 viii 2002, J. Gerlach (ZMBN).

This damaged specimen illustrated in Figures 42-43 keys to T. pallidissimus in Ekrem (2001), but differ in several details. The clypeus has 9 setae and there are 8 inner verticals, 2 outer verticals and 1 postorbital. The thorax has 7 dorsocentrals and 9 acrostichals. The cuneiform wing (Fig. 42) is $0.95 \mathrm{~mm}$ long with a VR of 1.08. The anal point (Fig. 43) appears to be simple with 10 setae medially on tergite IX. The gonocoxite is $98 \mu \mathrm{m}$ long, the superior volsella $39 \mu \mathrm{m}$ long with a $24 \mu \mathrm{m}$ long digitus, the inferior volsella $68 \mu \mathrm{m}$; the median volsella has some apically split setae; and the inferior volsella is $68 \mu \mathrm{m}$ long. Antenna and legs are lost and the hypopygium is crushed.

Tanytarsus atomarius Kieffer

Tanytarsus atomarius Kieffer, 1918, : 72. 

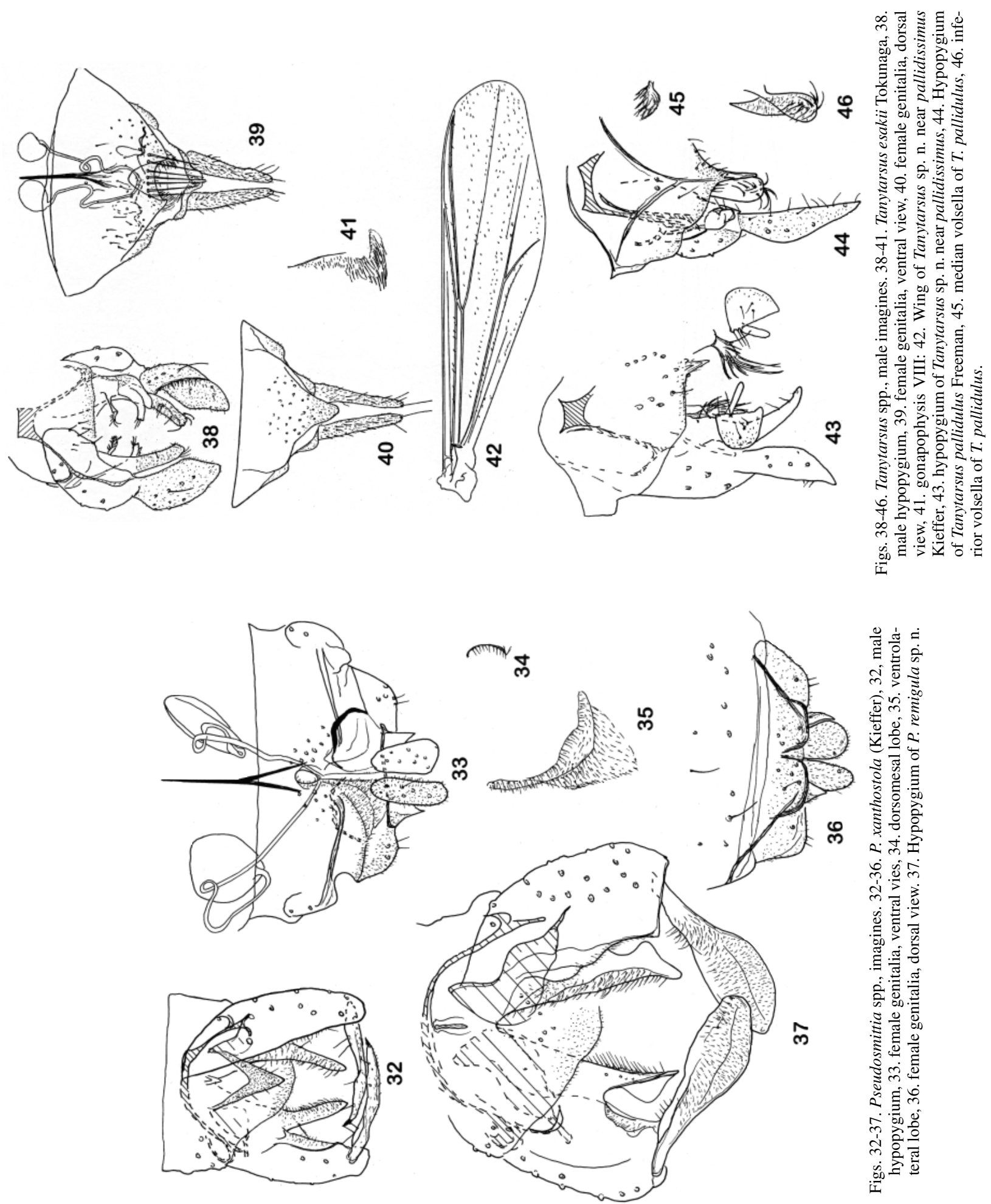
Tanytarsus (Tanytarsus) atomarius Kieffer ; Freeman $1958: 337$.

Tanytarsus atomarius Kieffer ; Freeman \& Cranston 1980 : 201, Ekrem 2001 : 27.

Tanytarsus pallidissimus Kieffer, 1911b, pro parte.

According to Freeman (1958: 338) the type series of T. pallidissimus from Mahé included three males and three females probably belonging to $T$. atomarius. The species otherwise is known from South Africa.

\section{Tanytarsus (Tanytarsus) pallidulus Freeman}

(Figures 44-46)

Tanytarsus (Tanytarsus) pallidulus Freeman, 1954 : 24.

Tanytarsus (Tanytarsus) pallidulus Freeman ; Freeman 1955a : 35, 1955b : 380, $1958: 333$.

Tanytarsus pallidulus Freeman ; Freeman \& Cranston 1980 : 201, Cranston \& Judd 1989 : 270, Ekrem $2001: 27$.

Material examined : SEYCHELLES: Mahé, Marc aux Cochons, 6 ơ, 29 viii 2002, J. Gerlach (ZMBN).

The species is previously known from South Africa, Mozambique, Nigeria, Zimbabwe, Democratic Republic of Congo, and Saudi Arabia (Cranston \& Judd 1989). New to the Seychelles.

\section{Tanytarsus sp.}

Material examined : SEYCHELLES : Silhouette, La Passe Reservoir, 4 \&, 7-14 vii 2001, J. Gerlach (ZMBN)

These four females could belong to one of the above species.

\section{Polypedilum (Tripodura) silhouettarium sp. n}

(Figure 47).

Material examined: Holotype : $0^{\prime}$, SEYCHELLES : Silhouette, Gratte Fesse, powdery rotten wood,

13 vii 2000, J. Gerlach (ZMBN Type No.405). Paratypes : SEYCHELLES: As holotype, $40^{7}(\mathrm{ZMBN}$, UMZC, BMNH) ; Silhouette, La Passe (above Dauban mausoleum), Malaise, 2 o', 1-4 vii 2000, J. Gerlach (ZMBN).

Diagnostic characters : The species differ from other Afrotropical members of the subgenus except $P$. aegyptium Kieffer (Vårdal et al. 2002 : 388) by having lateral projections on each side of the anal point, and subtriangular superior volsella. It differs from $P$. aegyptium by having a more sharply pointed superior volsella with two inner subapical spine-like setae, several inner subapical weak setae or strong microtri- chiae, two outer subapical setae and one inner median seta.

MALE IMAGO (n=6-7 except when otherwise stated)

Total length $12.40-2.79,2.59 \mathrm{~mm}$. Wing length 1.26$1.41,1.31 \mathrm{~mm}$. Total length/wing length 1.91-2.14, 1.98. Wing length/length of profemur 1.84-2.00, 1.93. Coloration light brown with darker thoracic markings.

Head. AR 1.15-1.35, 1.26. Ultimate flagellomere

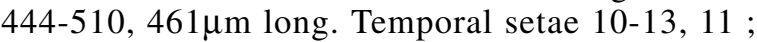
consisting of 5-7, 6outer verticals and 4-6, 5 postorbitals. Clypeus with 16-23, 19 setae. Tentorium 108-128, $118 \mu \mathrm{m}$ long; 26-30, $27 \mu \mathrm{m}$ wide. Stipes 116-131, $122 \mu \mathrm{m}$ long. Palpomere lengths (in $\mu \mathrm{m}$ ) : 34-45, 38; 38-56, 45 ; 90-109, 97 (5) ; 98-126, 114 (5) ; 173-214 (2). Third palpomere with 2 lanceolate sensilla clavata, 19-23 um long.

Thorax. Antepronotum with 0-1, 0 lateral setae. Dorsocentrals 11-14, 12 ; acrostichals 12-22, 16 ; prealars $4-5,4$; no supraalar seta. Scutellum with $10-12,11$ stronger posterior setae and 4-6, 5 weaker anterior row of setae.

Wing. VR 1.30-1.38, 1.34. Brachiolum with 1 seta ; $\mathrm{R}$ with $15-17,16$ setae ; $\mathrm{R} 1$ with $12-13,13 ; \mathrm{R}_{4+5}$ with 21-28, 25; M or RM with 1-3, 1 seta; other veins bare. Squama with 4-9, 6 setae.

Legs. Spur of front tibia 38-45, $43 \mu \mathrm{m}$ long including 11-15, $12 \mu \mathrm{m}$ long apical spine; spur of middle tibia 45-51, $46 \mu \mathrm{m}$ long including comb; of hind tibia 53-68, $58 \mu \mathrm{m}$ long. Width at apex of front tibia 41-45, $43 \mu \mathrm{m}$; of middle tibia $45-51,46 \mu \mathrm{m}$; of hind tibia 49 $53,50 \mu \mathrm{m}$. Lengths (in $\mu \mathrm{m}$ ) of front to hind femora : $633-747,678$; 680-775, 726 ; 690-803, 736 ; of front to hind tibiae : $369-416,388 ; 586-652,612 ; 624-737$, 668 ; of $\mathrm{ta}_{1}-\mathrm{ta}_{5}$ of mid leg $(\mathrm{n}=1): 340,187,123,76,38$. Ratios of mid leg $(n=1)$ : LR 0.58, BV 3.84, SV 3.81, BR 4.2.

Hypopygium (Fig. 47). Anal point 71-128, $89 \mu \mathrm{m}$ long ; 26-30, $29 \mu \mathrm{m}$ wide at apex ; $41-53,46 \mu \mathrm{m}$ wide at lateral projections. Tergite IX with 4-10, 6 median setae basal of anal point and 11-18, 16 setae underneath and lateral of point. Laterosternite IX with 2-3, 3 setae. Phallapodeme 86-113, $95 \mu \mathrm{m}$ long ; transverse sternapodeme $30-45,37 \mu \mathrm{m}$ long. Gonocoxite 136143, $137 \mu \mathrm{m}$ long ; inferior volsella long 105-124, 114 $\mu \mathrm{m}$ long, with 8-10, 9 apical setae ; superior volsella 49-60, $54 \mu \mathrm{m}$ long ; with 2 strong spine-like inner apical setae, several weak setae or strong microtrichia, 1 median inner seta, and 2 outer apicolateral setae. Gonostylus 146-154, $151 \mu \mathrm{m}$ long. HR 10.88-0.92, 0.91 ; HV 1.61-1.81, 1.72. 


\section{Distribution}

The species is known only from two localities on Silhouette, the main settlement area at La Passe and the high altitude forest at Gratte Fesse.

Polypedilum (Polypedilum) brunneicorne (Kieffer) Chironomus brunneicornis Kieffer, 1911b : 352.

Chironomus pandani Kieffer, 1911b : 356.

Polypedilum (Polypedilum) brunneicorne (Kieffer) ; Freeman 1958 : 295, Freeman \& Cranston 1980 : 196.

Material examined : SEYCHELLES : Mahé, Marc aux Cochons, 1 ơ, 29 vii 2002, J. Gerlach (ZMBN); Silhouette, Grande Barbe, riverside, grass under Tabebuia/ Terminalia, Malaise, 1 o', 22-23 vii 2000, J. Gerlach (ZMBN)

The species also is known from West Africa. The more widespread $P$. dewulfi Goetghebuer may be a synonym. Both the locality on Mahé and on Silhouette are marshlands.

\section{Polypedilum (Polypedilum) glabripenne (Kieffer)}

(Figure 49)

Tanytarsus glabripennis Kieffer, 1911b : 359.

Polypedilum (Polypedilum) glabripennis (Kieffer); Freeman 1958: 296.

Polypedilum glabripenne (Kieffer) ; Freeman \& Cranston 1980 : 197.

Material examined : SEYCHELLES : Mahé, Marc aux Cochons, 4 ơ 29 viii 2002, J. Gerlach (ZMBN).

Diagnostic characters : The absence of wing markings and spots on thorax, the small size (wing length $0.8 \mathrm{~mm}$ ), the cuneiform wing with 2 setae on squama, and the hypopygium with superior volsella broad-based and curved and with 2 inner basal setae and 2 outer lateral setae readily separate the male imago from other species of the genus.

\section{MALE IMAGO $(n=2-4)$}

Total length $1.29-1.35,1.34 \mathrm{~mm}$. Wing length $0.82-$ $0.84,0.83 \mathrm{~mm}$. Total length/wing length 1.57-1.63, 1.61. Wing length/length of profemur 2.02-2.22, 2.09. Coloration yellowish with reddish thoracic markings.

Head. Antenna lost. Temporal setae 6-8, 7 ; consisting of 4-6, 5 outer verticals ; and 2 postorbitals. Clypeus with 4-10 setae. Tentorium 86-94 $\mu \mathrm{m}$ long, $11 \mu \mathrm{m}$ wide. Stipes $68-83 \mu \mathrm{m}$ long. Basal palpomere $15-19$, $18 \mu \mathrm{m}$ long ; second palpomere 26-29, $27 \mu \mathrm{m}$ long ; other palpomeres lost.

Thorax. Median antepronotal lobes reduced, antepronotum with 1 lateral seta. Dorsocentrals7-8, 7; acrostichals 8-10, 10; prealars 3; no supraalar seta. Scutellum with 4 setae.

Wing. Wing cuneiform. VR 1.31-1.36, 1.33. Brachiolum with 1 seta, $\mathrm{R}$ with 11 setae $; \mathrm{R}_{1}$ with $5 ; \mathrm{R}_{4+5}$ with $15-18,16$ setae : other veins bare. Squama with $2-$ 3, 2 setae.

Legs. Spur of front tibia pointed, $19 \mu \mathrm{m}$ long ; of middle tibia 30-36 $\mu \mathrm{m}$ long ; of hind tibia 30-34 $\mu \mathrm{m}$ long. Width at apex of front tibia $23-26 \mu \mathrm{m}$; of middle tibia 24-26 $\mu \mathrm{m}$; of hind tibia 26-30, $27 \mu \mathrm{m}$. Lengths (in $\mu \mathrm{m}$ ) of front to hind femora : 369-416, 398 ; 378406 ; 369-435, 415 ; of front to hind tibiae : 184-198, $190 ; 265-293 ; 331-369,353$.

Hypopygium (Fig. 49). Anal point slender, 23$30 \mu \mathrm{m}$ long. Tergite IX with V-shaped tergal band, with 2-5, 4 setae between bands and 6-8, 7 posterior setae. Laterosternite IX with 1-2 setae. Phallapodeme 45-51, $48 \mu \mathrm{m}$ long ; transverse sternapodeme $19 \mu \mathrm{m}$ long. Gonocoxite 71-83 $\mu \mathrm{m}$ long; inferior volsella long 53-60, $56 \mu \mathrm{m}$ long, with 6 apical setae ; superior volsella 34-38, $36 \mu \mathrm{m}$ long, with 2 inner basal setae and 2 outer lateral setae. Gonostylus 64-75 $\mu \mathrm{m}$ long. HR 1.10-1.20, HV 1.83-2.03.

\section{Remarks}

These specimens keys to $P$. glabripenne in Freeman (1956) and the association appear reasonable certain.

\section{Distribution}

The species previously was known only from the female holotype from Mahé. The male described by Kieffer (1911b) is lost.

\section{fer)}

Polypedilum (Polypedilum) melanophilum (Kief-

(Figure 48)

Chironomus melanophilus Kieffer, 1911b : 355.

Chironomus limnocharis Kieffer, 1911b : 357.

Chironomus nocticolor Kieffer, 1911b : 357.

Polypedilum brunneum Freeman, 1954 : 178.

Polypedilum (Polypedilum) melanophilus (Kieffer); Freeman 1958: 296.

Polypedilum (Polypedilum) melanophilum (Kieffer); Freeman \& Cranston 1980 : 197.

Material examined : SEYCHELLES : Mahé, Marc aux Cochons, 29 viii 2002, J. Gerlach (ZMBN).

The hypopygium is shown in Fig. 48. The species is known from the Seychelles, Chad, Ivory Coast, Nigeria and South Africa.

Lepidopodus nigratipes (Kieffer) 
Chironomus nigratipes Kieffer, 1911b : 358.

Lepidopodus nigratipes (Kieffer) ; Freeman 1958 : 326, Freeman \& Cranston 1980 : 192.

The species and genus is known only from a single female from Mahé. The combination of scales on the legs, lack of pulvilli and an antepronotum reduced centrally but produced laterally as short tubercles make the genus unique.

\section{Dicrotendipes binotatus (Kieffer)}

(Figures 50-55)

Chironomus binotatus Kieffer, 1911b : 354.

Chironomus seychellensis Kieffer, 1911b : 356 (in part).

Chironomus (Dicrotendipes) binotatus (Kieffer) ; Freeman 1957: 367.

Dicrotendipes binotatus (Kieffer) ; Freeman \& Cranston 1980 : 190.

Material examined : SEYCHELLES : Silhouette, Grande Barbe, 20 07, 6 i 2002, J. Gerlach (ZMBN, UMZC, BMNH); Curieuse, 6 o", 20 iii 2003, J. Gerlach (ZMBN).

There is some slight difference between the specimens from Silhouette (Figs 50-52) and those from $\mathrm{Cu}$ rieuse (Figs 53-55). While most specimens from of those from Silhouette appear closer to D. chambiensis Goetghebuer, those from Curieuse clearly belong to $D$. binotatus. However, there are intermediate specimens. D. chambiensis most likely is a junior synonym.

D. binotatus previously was recorded from Mahé and also is known from Mozambique and Réunion.

\section{Kiefferulus chloronotus (Kieffer)}

(Figures 56, 59, 62, 65)

Chironomus chloronotus Kieffer, 1911b : 355.

Chironomus niloticus Kieffer, 1923 a : 150.

Chironomus latilobus Kieffer, 1923 b : 384 ; Freeman 1955 b : 371.

Chironomus henrardi Goetghebuer, 1936 : 475.

Chironomus (Dicrotendipes) chloronotus (Kieffer) ; Freeman $1957: 371$.

Kiefferulus chloronotus (Kieffer) ; Freeman \& Cranston 1980 : 191.

Material examined : SEYCHELLES: Silhouette, Grande Barbe, Scaevola beach crest, Malaise, $20^{7}, 22-$ 23 vii 2000, J. Gerlach (ZMBN) ; Silhouette, Grande Barbe, 8 o', 6 i 2002, J. Gerlach (ZMBN) ; Fregate, 3 $0^{7}, 1$ x 2002, J. Gerlach (ZMBN) ; Curieuse, 15 o', 18

\section{ㅇ, 20 iii 2003, J. Gerlach (ZMBN, UMZC, BMNH).}

The type locality is on Mahé. The species is widespread Afrotropical. The specimens from the Seychelles, however, are smaller and with thinner, more parallel-sided apical portion of the gonostylus and the continental species should perhaps be named $K$. niloticus. The variation, however, also within continental Africa is large. The minute frontal tubercles (Fig. 56) are common to all members of the genus Kiefferulus Goetghebuer.

\section{Chironomus seychelleanus Kieffer}

(Figures 57, 60, 63, 66)

Chironomus seychelleanus Kieffer, 1911b : 356.

Chironomus apicalis Kieffer, 1908 : 162.

Chironomus callichirus Kieffer, 1911b : 352 (preoccupied by Chironomus callichirus Kieffer, 1911a : 160).

Chironomus mahensis Kieffer, 1912 : 175 (replacement name for Chironomus callichirus Kieffer, 1911b, preoccupied by Chironomus callichirus Kieffer, 1911a: 160).

Chironomus albomarginatus Kieffer, 1924 : 260 ; Freeman 1955 b : 370.

Chironomus nivalis Freeman, 1954 a : 17 ; Freeman 1955 a : 13.

Chironomus (Chironomus) callichirus Kieffer ; Freeman $1957: 341$.

Chironomus callichirus Kieffer ; Freeman \& Cranston $1980: 187$

Chironomus seychelleanus Kieffer ; Cranston \& Judd $1989: 251$.

Material examined : SEYCHELLES : Mahé, Fisherman's Cove, marsh, 4 o', 1 \%, 29 viii 2002, J. Gerlach (ZMBN, UMZC).

Widespread Afrotropical including Madagascar and Réunion, Saudi Arabia and Oman (Cranston \& Judd 1989).

\section{Chironomus linearis Kieffer}

(Figures 58, 61, 63, 67)

Chironomus linearis Kieffer, 1911 b : 353.

Chironomus leptogastrus Kieffer, 1911 b : 354.

Chironomus (Calochironomus) rostratiforceps Kieffer, $1923: 383$

Chironomus (Chironomus) linearis Kieffer ; Freeman $1957: 343$.

Chironomus linearis Kieffer ; Freeman \& Cranston $1980: 188$

Material examined : SEYCHELLES : Silhouette, Grande Barbe, Scaevola beach crest, Malaise, 6 ㅇ, 2223 vii 2000, J. Gerlach (ZMBN) ; Silhouette, Grande 

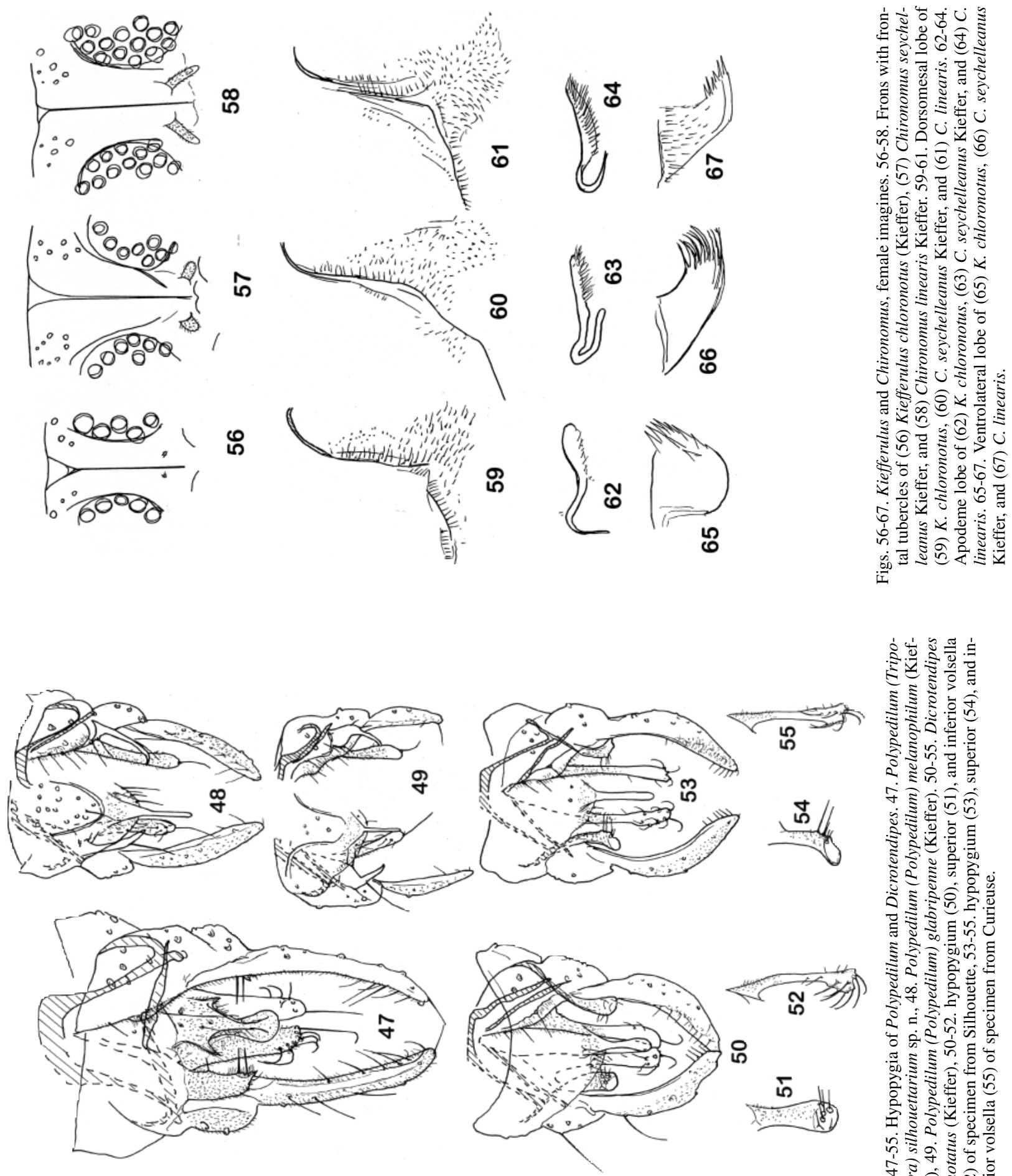

눈

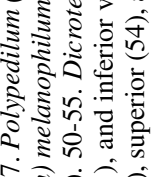

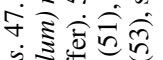
跣 今.

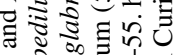

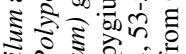

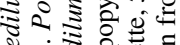

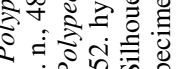
पे क्रें की की

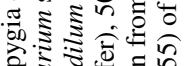
के

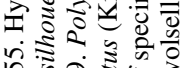

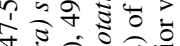

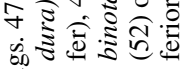


Barbe, 4 0’, 6 i 2002, J. Gerlach (ZMBN, UMZC); Anonyme Island, 1 \&, 13 xii 2001, J. Gerlach (ZMBN); Curieuse, 2 ơ, 20 iii 2003, J. Gerlach (ZMBN).

The type locality is on Mahé. Also known from Madagascar, Zimbabwe and South Africa.

\section{Notes on biogeography}

Twenty-eight species of chironomides are known from the Seychelles (Table 5, Fig.68.) There is a clear relationship between size of the islands and number of species recorded. However, some large islands such as Praslin (2,756 ha) and La Digue (1,010 ha) have no re-

Table 5. Island names, positions, areas and number of chironomid species known from each island.

\begin{tabular}{llll}
\hline Island & Position & Area in ha & $\begin{array}{c}\text { No. of chironomid } \\
\text { species }\end{array}$ \\
\hline Mahé & $4-5^{\circ} \mathrm{S} 55-56^{\circ} \mathrm{E}$ & 15,252 & 23 \\
Silhouette & $4.29^{\circ} \mathrm{S} 55.12^{\circ} \mathrm{E}$ & 1,995 & 12 \\
Curieuse & $4.15^{\circ} \mathrm{S} 55.440 \mathrm{E}$ & 286 & 3 \\
Fregate & $4.35^{\circ} \mathrm{S} 55.60^{\circ} \mathrm{E}$ & 219 & 1 \\
North & $4.240 \mathrm{~S} 55.150 \mathrm{E}$ & 210 & 1 \\
Alphonse & $7.05^{\circ} \mathrm{S} 52.50^{\circ} \mathrm{E}$ & 174 & 1 \\
Anonyme & $4.50^{\circ} \mathrm{S} 5.52^{\circ} \mathrm{E}$ & 9.5 & 2 \\
\hline
\end{tabular}

cords of chironomids indicating that more sampling are needed at closer intervals to get a more exact picture of the distribution. The fauna of the Praslin National Park is generally scarce due to the dry nature of the woodland, which means that there may be few suitable habitats for chironomids (Gerlach 2003). All the islands with records of chironomids are of granitic origin except for the coralline Alphonse Island in the Amirante Isles. The single species recorded from North and Alphonse is the marine intertidal Tanytarsus esakii, while the only species recorded from Fregate Island is the freshwater species Kiefferulus chloronotus.

Most of the species are known only from the Seychelles. However, some species among the probably marine intertidal species are also known from Micronesia or have close relatives in the Oceanic or Oriental or Eastern Palaearctic regions, while other species are widespread Afrotropical. A few species do not occur to have close relatives anywhere and may be true relicts.

In the first group are Semiocladius brevicornis, known from the Caroline Islands, and Pseudosmittia triangula and Tanytarsus esakii both known from Caroline and Marshall Islands. Pseudosmittia melanostola appear to be related to P. macrobrachia (Edwards) from Samoa, Pseudosmittia xanthostola may be the sister species of $P$. bifurcata from Kiribati and Japan, Pseudosmittia remigula appears related to $P$. brachydicrana (Edwards) known from Micronesia,
Marshall Islands, Diego Garcia, Hawaii and Jamaica. Clunio gerlachi may be close to C. pacificus from Western Samoa, American Samoa, Australia, Belau, Northern Marianas, Vanuatu, Ryukyus and Japan (Cranston \& Martin 1989), and C. tuthilli from Marshall Islands. Rather than the northern Gondwanan Afrotropical-South Asia track (Track 3 in Sæther 2000) the similarities with the Australasian and Oceanic regions may be a result of direct dispersal with flotsam (Sæther \& Ekrem 2003).

Species occurring in continental Africa includes : Tanytarsus atomarius, Tanytarsus pallidulus, Polypedilum (Polypedilum) brunneicorne, Polypedilum (Polypedilum) melanophilum, Dicrotendipes binotatus, Kiefferulus chloronotus, Chironomus seychelleanus and Chironomus linearis. Paramerina minima obviously is close to Paramerina vaillanti Fittkau known from Algeria, the Canary Islands, Jordan, Saudi Arabia, Zimbabwe and South Africa; and Polypedilum (Tripodura) silhouettarium is close to the widespread P. aegyptium known from the Afrotropical, Palaearctic and Oriental regions.

Tanypus complanatus, Larsia pallidissima, Gymnometriocnemus (G.) mahensis, Smittia megalochirus and Lepidopus nigratipes all have some characters which makes them unique within their genus, or in the case of Lepidopus which is known only from the female, within the subfamily. This could indicate an early divergence from other Afrotropical species and perhaps true Gondwanan relicts. 


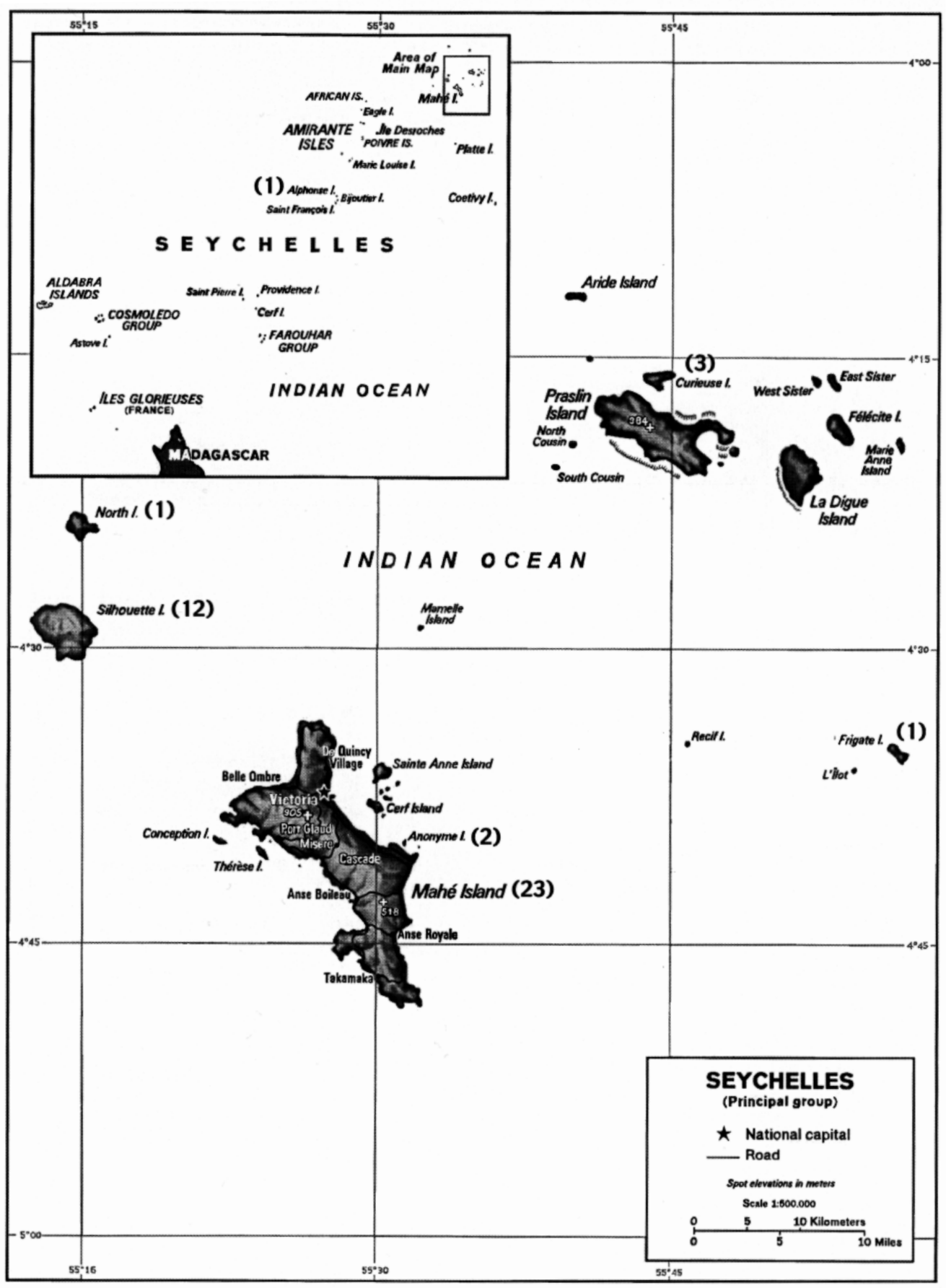

Fig. 68. Map of the Seychelles. Number of species recorded from different islands in parentheses.

\section{Acknowledgements}

I am grateful to Dr. Justin Gerlach, University Museum of Zoology, Cambridge for the material from the recent expedition and for much information about the expeditions and the islands, and to Dr. John Chainey, The Natural History Museum, London, for the loan of types of Pseudosmittia from the Seychelles. Gladys Ramirez made the slide preparations. 


\section{References}

Armitage P.A., Blackburn J.H., Nilsson A.N. \& Malmquist B. 1995. - Chironomidae in freshwater habitats in Tenerife, Canary islands. Pages 379-388 in Cranston P.S. (ed.). Chironomides from genes to ecosystems. CSIRO Publ.

Coffman W.P., Cranston P.S., Oliver D.R. \& Sæther O.A. 1986. The pupae of Orthocladiinae (Diptera: Chironomidae) of the Holarctic region - Keys and diagnoses. Pages 147-296 in Chironomidae of the Holarctic region. Part 2. Pupae. Wiederholm, T. (ed.) Ent. scand., Suppl. 28.

Cranston P.S. \& Judd D.D. 1989. - Diptera: Fam. Chironomidae of the Arabian Peninsula. Fauna Saudi Arabia, 10, 236-89.

Cranston P.S. \& Martin J. 1989. - 26. Family Chironomidae. In Evenhuis N. L. (ed.), Catalog of the Diptera of the Australasian and Oceanic Region. Bishop Mus. Spec. publ., 86, 252-274.

Edwards F.W. 1926. - On marine Chironomidae (Diptera); with descriptions of a new genus and four new species from Samoa. Proc. zool. Soc. Lond., 51, 779-806.

Edwards F.W. 1928. - Nematocera. In: Insects of Samoa. Bull. Br Mus. nat. Hist,. 8: 23-102.

Ekrem T., 2001. - A review of Afrotropical Tanytarsus van der Wulp (Diptera: Chironomidae). Tijdschr. Ent., 144, 5-40.

Fittkau E.J. 1962. - Die Tanypodinae (Diptera: Chironomidae) (Die Tribus Anatopyniini, Macropelopiini und Pentaneurini). Abh. Larvalsyst. Insekten, 6, 1-453.

Freeman P. 1954 a. - Chironomidae (Diptera) from western Cape Province -III. Proc. R. Ent. Soc. Lond. (B), 23, 17-25.

Freeman P. 1954. b - Chironomidae (Diptera) from western Cape Province -IV. Proc. R. Ent. Soc. Lond. (B), 23, 172-280.

Freeman P. 1955 a. - Chironomidae (Diptera: Nematocera). Explor. Parc. Natn Albert Miss. G. F. de Witte, 83, 1-41.

Freeman P. 1955 b. - Diptera (Nematocera): Chironomidae. S. Afr. Animal Life, 2, 361-381.

Freeman P. 1955 c. - A study of the Chironomidae (Diptera) of Africa south of the Sahara. Part I. Bull. Br. Mus. nat. Hist., Ent., 4, 167,1 plate.

Freeman P. 1956. - A study of the Chironomidae (Diptera) of Africa south of the Sahara. Part II. Bull. Br. Mus. nat. Hist., Ent., 4, 287368.

Freeman P. 1957. - A study of the Chironomidae (Diptera) of Africa south of the Sahara. Part III. Bull. Br. Mus. nat. Hist., Ent., 5, 324 426.

Freeman P. 1958. - A study of the Chironomidae (Diptera) of Africa south of the Sahara. Part IV. Bull. Br. Mus. nat. Hist., Ent., 6, 264 363.

Freeman P., \& Cranston P.S. 1980. - 11. Family Chironomidae. Pages 175-202 in Crosskey I. W. (ed.). Catalogue of the Diptera of the Afrotropical Region. British Museum (Natural History), London.

Gerlach J. 2003. - The biodiversity of the granitic islands of Seychelles. First report of the Indian Ocean Biodiversity Assessment 2000-2005. Biodiversity assessment celebrating the centenary of the Percy Sladen Trust Expedition to the Indian Ocean. The Nature Protection Trust of Seychelles, 39 pp.

Goethgebuer M. 1936. - Chironomides du Congo belge. Revue Zool. Bot. afr., 28, 453-492.

ICZN (1999) International Code of Zoological Nomenclature. Fourth Edition. International Trust for Zoological Nomenclature, London, $x x i x+306 \mathrm{pp}$.

Kieffer J.J. 1908. - Chironomidae. In: Zoologische und anthropologische Ergebnisse einer Forschungsreise im westlichen und zen- tralen Südafrika ausgeführt in den Jahren 1903-1905. Erster Band: Systematik und Tiergeographie. IV. Insecta (Erster Serie). D. Diptera (I). Denkschr. Med.-naturw. Ges. Jena, 13, 155-162.

Kieffer J.J. 1911a. - Description de nouveaux Chironomides de l'Indian Museum de Calcutta. Rec. Indian Mus., 6, 113-177.

Kieffer J.J. 1911b. - The Percy Slade Trust expedition to the Indian Ocean in 1905, under the leadership of Mr J. Stanley Gardiner. Vol. 3. No. XV. - Diptera, Chironomidae der Seychellen-Inseln, aus der Sammlung von Mr H. Scott. Trans. Linn. Soc. of Lond. (2nd Ser. Zool.), 14, 331-366.

Kieffer J.J. 1912. - Description de quatre nouveaux insectes exotique. Boll Lab. Zool. gen. Agr. Portici, 6, 171-175.

Kieffer J.J. 1918. - Chironomides d'Afrique et d'Asie conservés au Musée National Hongrois de Budapest. Annls hist.-nat. Mus. natn. hung., 16, 31-136.

Kieffer J.J. 1923 a. - Chironomides de l'Afrique équatoriale (3e partie). Annls Soc. Ent. France, 92, 149-204.

Kieffer J.J. 1923 b. - Chironomariae [sic] de l'Afrique du Sud. Annls Soc. sci. Brux. (Docums C. r.), 42, 382-388.

Kieffer J.J. 1924. - Six nouveaux Chironomides d'Afrique. Annls Soc. sci. Brux. (Docums C. r.), 43, 255-261.

Moller Pillot H.K.M. \& Beuk P.L.T. 2002. Family Chironomidae. in Beuk P.L.T. (Ed). Checklist of the Diptera of the Netherlands. KNNV, Utrecht, pp. 1-448.

Murray D.A. \& Fittkau E.J. 1989. -The adult males of Tanypodinae (Diptera: Chironomidae) of the Holarctic region - Keys and diagnoses. Pages 37-123 in Wiederholm T. (ed.). Chironomidae of the Holarctic region. Part 3. Adult males. Ent. scand., Suppl. 34.

Sæther O.A. 1980. - Glossary of chironomid morphology terminology (Diptera: Chironomidae). Ent. Scand., Suppl., 14, 1-51.

Sæther O.A. 2000. - Zoogeographical patterns in Chironomidae (Diptera). Verh. Int. Ver. Limnol., 27, 209-302.

Sæther O.A., Ashe P. \& Murray D.A. 2000. - Family Chironomidae. Pages 113-334 in Papp, L. \& Darvas B. (eds). Contributions to a Manual of Palaearctic Diptera (with special reference to the flies of economic importance). Science Herald, Budapest; Vol. 4. Appendix A.6.

Sæther O.A. \& Ekrem T. 2003. - Biogeography of afrotropical Chironomidae (Diptera). Cimbebasia, 19, 175-191.

Sæther O.A. \& Ferrington L. C. jr. 1997. - A review of the genus $S e$ miocladius Sublette \& Wirth (Diptera: Chironomidae). Aquat. Insect., 19, 219-236.

Spies M. \& Sæther O.A. 2004 - Notes and recommendations on taxonomy and nomenclature of Chironomidae (Diptera). Zootaxa, $752,1-90$.

Strenzke K. 1960. - Metamorphose und vervandschaftsbeziehungen der Gattung Clunio Hal. (Dipt.) (Terrestrische Chironomiden XXIV). Ann. Zool. Soc. zool. bot. fenn. Vanamo, 22, 30.

Tokunaga M. 1935. - Chironomidae from Japan (Diptera), V. Supplementary report on the Clunioninae. Mush, 8, 1-20.

Tokunaga M. 1936. - Chironomidae from Japan (Diptera), VIII. Marine or seashore Spaniotoma, with descriptions of the immature forms of Spaniotoma nemalione sp. nov. and Tanytarsus boodlece Tokunaga. Philipp. J. Sci., 60, 303- 321.

Tokunaga M. 1940. - Ceratopogonidæ and Chironomidæ from the Micronesian islands. Philipp. J. Sci., 71, 205-229.

Tokunaga M. 1964. - Insects of Micronesia. Diptera: Chironomidae. Bernice P. Bishop Mus., 12, 485-628.

Vårdal H., Bjørlo A. \& Sæther O.A. 2002. - Afrotropical Polypedilum Kieffer subgenus Tripodura Townes with a review of the subgenus (Diptera: Chironomidae). Zool. Scr., 31, 331-402. 